\title{
Distopik Bilim Kurgu Sinemasında Gelecek Mekânları ve Mimari Öngörüler*
}

\author{
Future Spaces and Architectural Projections in Distopic Science Fiction Cinema \\ Büşra Ünver, İç Mimarlık Bölümü, Haliç Üniversitesi
}

\section{Özet}

Sinema ve mimarlığın varoluşuna ilişkin ortak unsur olan 'mekân' kavramının geleceğini konu alan bu çalışmanın amacı, distopik bilim kurgu sineması aracılı̆̆ı ile mekân tasarımına ve mimarlığa ait kurguların ve öngörülerin araştırılmasıdır. Bu amaçtan hareketle bu çalışmada incelenen filmlerde özellikle teknolojik etkilerin mekân tasarımlarında ne gibi değişikliklere yol açabileceği sorularına cevap aranmıştır. İncelenen filmler içerdikleri ortak mekânlar doğrultusunda 'kent', 'ev/konut', 'sosyal alanlar' ve 'ticari mekânlar' başlıkları altında ele alınmıştır. Distopik türde yer alan bilim kurgu filmlerinden örneklem olarak 10 film üzerinde durulmuștur. $\mathrm{Bu}$ filmler, 'Metropolis', 'Brazil', 'Ghost in the Shell', 'Gattaca', 'The Fifth Element', 'Minority Report', 'The Island', 'Wall E', 'Black Mirror Fifteen Million Merits' (dizi bölümü) ve 'Interstellar' olarak belirlenmiștir. Bu doğrultuda mekânsal dönüșümün gözlemlendiği filmlerde gelecek mekânlarında oluşabilecek sorunlar insan ve yaşam ile iliş̧kisi bağlamında tümdengelim yöntemi ile araştırılmıştır. Çalışmanın sonunda fiziksel mekânların önemlerini yitirseler dahi insanlar var olduğu sürece minimum düzeyde varlıklarını sürdürecek olmalarına karşın sanal ve teknoloji destekli mekânların giderek önem kazanacağının öngörüldügü saptanmıştır.Bu dönüşümün insan yaşamında birtakım olumlu sonuçlara neden olmasının yanında, mekânı insani ve yașanan olandan uzaklaștırabileceği, sosyal kopukluklara yol açabileceği, insanları yalnızlaştırabileceği, mekânın ve mimarlığın tanımlarını değiştirip dönüştürebileceği, teknolojinin ve dijital desteğin mekân tasarımlarına hâkim olacağı öngörülerinin çoğunlukta olduğu tespit edilmiştir.

Anahtar Sözcükler: Mekân, bilim kurgu, sinema, distopya, teknoloji, mimarlık.

Akademik disipin(ler)/alan(lar): İç Mimarlık, mimarlık, sinema.

\begin{abstract}
The aim of this study is to scrutinize the fictions and prescience of spatial design and architecture through dystopian science fiction cinema; while looking at the future of 'space' - a common element for both cinema and architecture. With this objective and through the chosen films, questions about how technological effects may alter spatial design were answered. The films were categorized according to the common spaces they included such as 'city', 'home/dwelling', 'social areas' and 'commercial spaces'. Ten science fiction films were chosen as case studies: 'Metropolis', 'Brazil', 'Ghost in the Shell', 'Gattaca', 'The Fifth Element', 'Minority Report', 'The Island', 'Wall E', 'Black Mirror - Fifteen Million Merits' (tv series episode) and 'Interstellar'. In these films that consist of spatial transformation, the problems related to the individual and life and that may occur in futuristic spaces, were analyzed through a deductive method. As a result, it was determined that virtual and technology-supported spaces will gradually gain importance even though physical spaces will continue to exist, although with deteriorating necessity, at the minimum level as long as humans exist. While this transformation causes some positive outcomes in the human life, it may also make space move away from the human and the living, lead to social disconnections, isolate people, change the definitions of space and architecture as well making technology and digital assistance dominate spatial design.
\end{abstract}

Keywords: Space, science fiction, cinema, dystopia, technology, architecture.

Academical disciplines/fields: Interior architecture, architecture, cinema.

\footnotetext{
* Bu çalışma, Mekânsal dönüşümlerin distopik bilimkurgu sineması aracıllı̆ı ile incelenmesi ve mimari öngörüler adlı doktora tezinden üretilmiştir.
}

- Sorumlu Yazar: Büșra Ünver, İç Mimarlık Bölümü, Haliç Üniversitesi.

- $\quad$ Adres: Haliç Üniversitesi, Sütlüce Mah. İmrahor Cad. No:82 Beyoğlu, İstanbul.

- e-posta: busraunver@halic.edu.tr

- ORCID: 0000-0002-9171-1988

- CCevrimiçi yayın tarihi: 15.07 .2020

- doi: $10.17484 /$ yedi.730583 


\section{Giriş}

Teknoloji ve bilgi çağı ile birlikte derin bir değişim geçirmekte olan mekân kavramının evrimi, hemen herkesçe benimsenen fiziksel-matematiksel tanımının yanında, soyut ve sanal tanımları da içeren bir kavram olma yönündedir. Bu durum, mekândan ayrı düşünülemeyen insan ile mekân etkileşiminde birtakım farklılıklar ortaya çıkarmaktadır. Teknolojinin yoğun etkisinin yadsınamayacağı bu çağda, insanlar teknolojiye dayalı mekânı üretirken ve deneyimlerken, mekânın tanımını ve gerçeklik algısını da değiştirmektedir.

Teknolojinin baskınlığı ile değişime uğramakta olan mekân, sinema perspektifinden bakıldığında geçirdiği evrim ve insan ile ilişkisi gözler önüne serilmektedir. Bu durum bilim kurgu sineması üzerinden incelendiğinde karşılaşılan en belirgin unsur pesimist yaklaşım olmuştur. Sinematografik anlatı üretiminde bulunan insanlar teknolojik gelişim ve değişimler karşısında endişelenerek, eleştirel bir yaklaşımla endișelerinin dışavurumu niteliğinde olan distopik gelecekler tasarlamışlardır. Distopyalar, bugünün teknolojik, toplumsal, etik, siyasi ve bilimsel çıkmazlarının eleştirilerek yeni dünyalar, kimi zaman evrenler, yaratılması ile oluşturulmaktadır. Tarkovski (2007, s. 194), geleceğin bugün ile bağlantısını "[...] içinde yașadığımız zaman aslında gelecekle çakıșıyor; yani, şimdiki zamanın içinde yakın gelecekte meydana gelecek önüne geçilmez bir felaketin bütün önkoşulları mevcut" şeklinde açıklamaktadır.

Bu bağlamda mimarlığın ve mekânların geleceği ile ilgili sorulara ve çıkmazlara farklı yollarla ve farklı disiplinler aracılığıyla cevap aranmaktadır. Yeni olanın ve geleceğin daha güvenilir ve tanıdık olmasının sağlanması da yaşanması olası sorunların öngörülmesi, anlașılması ve çözülmesi yolundan geçmektedir. Sinema ve mimarlığın varoluşuna ilişkin temel unsur olan mekân kavramının sinematografik anlatılar üzerinden ele alındığı bu çalışmanın amacı, distopik bilim kurgu sineması aracılığı ile mekân tasarımına ve mimarlığa ait öngörülerin izini sürmektir.

Çalışmada irdelenen filmler aracılığla mekân tasarımlarında özellikle teknolojik etkilerin insan mekân arakesitinde ne gibi değişikliklere yol açabileceği sorularına cevap aranmıştır. Mimari öngörülere örnekleri araştırmak amacıyla incelenen filmler 'kent', 'konut', 'sosyal alanlar' ve 'ticari mekânlar' kapsamlarında ortak mekânlar içerdiklerinden dolayı incelenen mekânlar bu 4 başlık altında ele alınmıştır. Distopik bilim kurgu sinemasından örneklem olarak 10 eser üzerinde durulmuştur. Sayıca oldukça fazla olan distopik filmler arasından seçim yapılarak, karşılaștırmalı ve paralel okumalara uygun, ortak mekânlar içeren filmler belirlenmiş ve çok sayıda film incelemek yerine çalışmanın nitekli olabilmesi amacıyla herbir mekân için 3 film ile sinırlandırılmıștır. İncelenen eserler, 'Metropolis' (Lang, 1927), 'Brazil' (Gilliam, 1985), 'Ghost in the Shell' (Oshii, 1995), 'Gattaca' (Niccol, 1997), 'The Fifth Element'(Besson, 1997), 'Minority Report' (Spielberg, 2002), 'The Island' (Bay, 2005), 'Wall E' (Stanton, 2008), 'Black Mirror - Fifteen Million Merits' (Lyn, 2011) ve 'Interstellar' (Nolan, 2014) olarak belirlenmiştir. Bu doğrultuda mekânsal evrimin gözlemlendiği filmlerden yola çıkılarak gelecek mekânları ve insanlar ile ilişkisi bağlamında mimari öngörü tespitlerinde bulunulmuştur.

\section{Sinemada Bilim Kurgu Distopyaları}

Varolușun bașlangıcından itibaren içinde bulunulan dünya dıșında bașka evrenler ve yașam alanları kurgulayan insanlar kendilerine yabancı ve yeni olan düşünceleri anlamlandırmaya çalışmışlardır. Düş görme ve fantazyalara gereksinim duyma, 21. yüzyıl toplumlarında, insanın gerçeklik ile kurduğu anlamlandırma ilişkilerindendir. Fantastik hikayeler, gezi ve serüven yazıları, masallar bilim kurgu türünün oluşumunun temel taşları olmuştur. Bilim kurguyu hikâyelerden, masallardan ayıran en önemli özellik ise insanın bilişsel yeteneğine seslenen bir söylem biçimi olan kurgu niteliği taşımasıdır (Oskay, 1982).

Bilim kurgunun sinema ile buluşmasının öneminin yadsınamayacak ölçüde büyük olmasının yanında 'bilimsel' değerinin azaldığı gibi görüşleri de beraberinde getirmiştir. Sontag bu konuda "Bilim kurgu filmleri bilim hakkında değildir. Sanatın en eski konusu olan felaket hakkındadır" demiștir (Sontag, 1965, s. 213). Sontag'a göre bilim kurgu, yazında ve sinemada farklı olumlu özelliklere sahiptir. Yazında kelimeler ile çerçevelendirilen kurgular, sinemada hayal gücü aracılığıyla yorumlanarak çeşitlenmektedir. Bu şekilde bilim kurgu sineması geniş ekranlarda felaketin estetik görünümleriyle, büyük yıkımlarda bulunan olağandışı güzellikler yaratmaktadır (Sontag, 1965, s. 213).

Endüstri devrimi ile başlayan süreçte teknoloji insanlık için bir kurtarıcı olarak görülmüş, geleceğin mükemmelleşmesinin büyük ölçüde teknoloji sayesinde olabileceği düşüncesi zihinlere yerleşmiştir. Fakat endüstrileşmenin getirdiği sosyal yapıdaki değişimler, çarpık kentleşme, çevre üzerinde meydana gelen geri dönüşsüz hasarlar, özellikle teknolojiye karşı huzursuzluk ve korku duyulmasına neden olmuştur. 
Dolayısıyla bilim kurgu, idealize dünyalardan çok korkular ve paranoyalar kurgulamaya başlamıştır. Bu nedenle çoğu bilim kurgu filmi insanların bilinçaltı korkularına ve endișelerine ayna tutar nitelikte olmuştur.

Kolektif bilinçaltı birikimi ile 19. yüzyılın sonlarına doğru, ütopyanın doğası siyasal, bilimsel, teknolojik ve sosyolojik etkiler ile birlikte değişmeye başlamış ve bunun sonucunda anti-ütopya, kara-ütopya, karşı ütopya olarak da adlandırılan 'distopya'lar ortaya çıkmıştır. Daha önceleri düşlenen ütopyalar zamanla distopyalara dönüşmüş, hayal edilen huzur ve refahın altında yatan karanlık kendini göstermeye başlamıștır. 'Distopya' kelimesi ilk kez 1868 yllında John Stuart Mill'in bir konuşmasında Thomas More tarafından literatüre kazandırılan 'ütopya' kelimesinden türetilerek kullanılmıştır. İrlanda toprak politikası hakkındaki konuşmasında Mill “(...) ütopyacı olmaktan ziyade distopyacı veya kakotopyacı (cacotopian) oldukları söylenebilir. Ütopya denilen şey uygulanabilir olmaktan uzak düssecek şekilde fazla iyi iken, bize önerdikleri şey uygulanabilir olmaktan uzak düșecek ş̧ekilde fazla kötüdür" söyleminde bulunmuștur (Claeys, 2010, s. 107).

Distopyalar, yaratıldıkları dönemin eleştirileri niteliğinde olup insanlara uyarılarda bulunmak amacıyla ortaya çıkmaktadırlar. Gerçekleșemeyecek kadar 'kötü' tasvir edilseler de yaşanmakta olan hayattan alınan ipuçları bu distopik kurguların özünü oluşturmaktadır. Distopyanın en çok konu alındığı yazın ve sinema türü ise bilim kurgudur. Özellikle teknolojinin gelişimi ile birlikte oluşan olumsuzluklar, distopik kurgular için önemli bir kaynak olmuştur. Bu nedenle bilim kurgu eserlerindeki ütopik düşler çoğu eserde yerini pesimist tavra yani distopyaya bırakmıştır. Teknoloji zaman içerisinde ilerledikçe distopik anlatılardaki kötümser yaklaşımlar da etkisini artırmıştır. Teknolojinin insanları esir alacağı, makinelerin dünyanın kontrolünü ele alacağı ve gerçeklikleri tanımlayacaklarına yönelik düşünceler gelişmiştir. İlerleyen teknolojinin güç sahiplerinin elinde önemli bir baskı aracına dönüşeceği korkusu, distopik bilim kurgu eserlerinin sıklıkla işlediği konular haline gelmiştir.

Distopik kurgular, çoğu zaman geleceğe referans vererek anlatılarının gerçekliklerinin kırılmasını sağlarlar. $\mathrm{Bu}$ durum toplumların yaşadıkları güncel olayları gerçeklikten koparmakta, aynı zamanda da geleceğin bilinmezliğini aydınlatmaktadır. Gelecek ile ilgili öngörülerde bulunulur. Bu öngörüler ütopik tavrın aksine sorunların su yüzüne çıkarıldığı, çarpıcı ve kötümser öngörülerdir. Fakat distopyalar doğaları gereği okuyucu ya da izleyicilere gerçek olma ihtimalini hep düşündürmektedir. Distopik öykülerin özellikle edebiyatta ve sinemada yoğun kullanımının nedeni de bahsedilen reel referanslar ile kurgulanan hayal ürünü dünyaların insanları düşündürmesi ve aydınlatmasıdır.

Bilim kurgu distopyaları için tasarlanmış hayal ürünü yaşam alanları, reel mekânlardan referanslar barındırmaktadır. Filmler, geleceğin resimlerini çizip, bu resimlerin içerisinde devam eden yaşamlar kurgulamaktadırlar. Bilim kurgu filmlerinin dünyaları, ideolojileri ve set tasarımları hikâyenin yaratıcısının mimari öngörüleri ile olușturulmaktadır. Bilim kurgunun dünya yaratma süreciyle mimari tasarım arasında büyük benzerlikler bulunmaktadır. İkisi de tanrısal bir ișe soyunarak yeni evrenler yaratırlar (Özakın, 2001, s. 82).

Bilim kurgu filmlerinde mimarlığa ve mekânlara reel hayatta olduğundan çok daha farklı bir açıdan bakılmakta, izleyiciler için yeni alternatifler sunularak ortak bilinçler oluşturulmaktadır. Bilim kurgu sineması mimarlık için bir kılavuz görevi görürken aynı zamanda yeni mimarlık ve mekân arayışlarında adeta bir test alanı niteliğindedirler. Bu bağlamda Özakın (2001, s. 83), tasarımcıların ve mimarların bilim kurgu türünden, türün yöntemleriyle yeni dünyalar yaratarak ya da önceden kurulmuş bilim kurgu dünyalarını çözümleyerek yararlanabileceklerini belirtmiştir.

Bilim kurgu türünde önemli edebi eserler vermiş olan Le Guin, bilim kurgunun, geçmişi anlamlandırmak ve geleceği düsslemek için oldukça geniş ve verimli bir alan olduğundan bahseder.

Bütün ciddi kurgu ürünleri gibi, doğru dürüst tasarlanmış bilim kurgu da ne kadar komik olursa olsun, gerçekte neler olup bittiğini, insanların aslında neler yapıp hissettiğini, insanın bu kocaman çuvaldaki, evrenin bu göbeğindeki, bu gelecek şeylerin rahmi ve geçmiş şeylerin kabrindeki, bu bitmeyen hikâyedeki bütün diğer her şeyle nasıl bir ilişki içinde olduğunu tanımlamaya çalışmanın bir yolu. Tüm kurgu ürünleri gibi bilim kurguda da İnsan'ı ait olduğu yerde, evrenin düzeninde ona ayrılmış olan noktada tutacak kadar geniş bir alan var; [...] (Le Guin, 2015, s. 68).

Bilim kurgu filmlerinde ilerleyen teknoloji ve yeni olanaklar ile değişen toplum, yeni mekânsal ihtiyaçları da beraberinde getirmektedir. Bu değişimler ıșığında varsayımsal tasarımlar yapılarak gelecek senaryoları doğrultusunda yeni mimari ve mekânsal oluşumlar filmlerde yer almaktadır. Filmlerdeki mekânlar ve 
yaşam biçimleri, bugünün toplumsal, ideolojik, etik, bilimsel dinamiklerinin etkileriyle fiziksel yaşam çevrelerinin dönüşümü sonucu ortaya çıkmaktadır.

Teknolojinin ve yeniliklerin yarattığı değişim süreci anlaşılır, özümsenir ve alternatif gelecekler kurgulanıp araştırılırsa, geleceğe müdahale etmeye, direnmeye, yaşamaya, planlamaya ve tasarlamaya olanak sağlanmıș olur (Ünver, 2016, s. 79). Muhtemel sorunların neler olabilecekleri tespit edildiği ve çözüm için gerekli olan bilgi ve donanıma sahip olunduğu zaman gelecek için 'yeni'yi üretmekte tedirginlik ve endişe yaşanmayacaktır.

\section{Distopyalarda Gelecek Mekânları ve Mimari Öngörüler}

Yeni olanın getirdiği karmaşıklık ve belirsizliğe yönelik, onu anlayacak ve olası sorunları belirleyip çözüm önerileri sunacak altyapıların hazırlanması ve gerekli araştırmaların yapılması gerekmektedir. Bu yaklaşım aracılığıyla da gelecek, gelmesi 'beklenen' değil, gelmesi 'planlanan' bir kavrama evrilecektir. Özellikle distopyalar üzerine yoğunlaşarak bilim kurgu filmlerindeki gelecek senaryolarını araştırmanın mimarlıkta bugünün hızla değișen dinamiklerini tespit etmek, gelecekte oluşabilecek sorunları ve çözümlerini üretebilmek için oldukça verimli bir çalıșma alanı olduğu düșünülmektedir. Bu amaçla incelenen filmlerde birtakım mekânlar belirlenerek filmin yaratıcılarının öngördükleri mimari ve mekânsal gelecek tasvirleri incelenmiştir.

\subsection{Kent: Toprağı Tüketmek - Dikeyde Yaşamak - Gezegenden Kopmak}

Döneminin eleștirisi niteliğinde olan distopik hikâyeler, kötümser bir yaklaşımla geleceği tasarlarken, üretildikleri dönem sorunlarına da ayna tutarlar. Erken dönem distopik bilim kurgu filmlerinde, kent yaşamına dair öngörülen gelecek vizyonlarında tarih boyunca süregelen toplumsal konuların vurgulandığ ve bu toplumsal modellerin fiziksel mekânlar ile ifade edildiği görülmektedir. Bunun nedeninin, özellikle endüstrileşme sonrası yaşanan toplumsal sınıf ayrımlarının insan ve kent yaşamına olan yıkıcı etkisi olduğu düşünülmektedir.

Filmler aracılığıyla küreselleşmenin şekillendirdiği, kaotik ve bölünmüş bir geleceğin kentleri görselleştirilmektedir. Orta sınıfın yok sayılıp gözden çıkarıldığı, varlıklı sınıfın ise kendi korunaklı alanlarında yaşadıkları bir dünyanın oluşacağı öngörüsü distopik bilim kurgu filmlerine hâkim olan düşüncedir (Ünver, 2016, s. 40).

Bilim kurgu sinemasında görselleştirilen mimari yapılar ve kent imajları, yüzeysel bir arka plan olmaktan öte, bugünün eleştirisini yaparak geleceğe yönelik düşleri ve korkuları ortaya koyma olanağı sağlayan kurgusal bir dünyanın kapılarını açmaktadır. Bilim kurgu sineması bu yönüyle, insanlara kentin mekânsal ve zamansal dönüşümünün fenomenolojik tarihinin anlaşılabilmesi için en uygun zemini sunmaktadır (Sobchack, 1997).

Bilim kurgu sineması erken dönem filmlerinde distopik örnekler olduğu kadar ütopik gelecek kent vizyonları da görülmektedir. Fakat özellikle 60 ve 70'lerden sonraki filmlerin tamamına yakınında distopik anlatılar bulunmaktadır. 90'larda ise geleceğin kentlerini çürüyen mekânlar ya da geçmișe ait kentsel imajların bozulmaları ile betimleyen görüntüler mevcuttur. Bu durum Mennel'a (2008) göre modernizmin vaatlerinin geçerliliğini yitirdiğine ve postmodern durumun belirdiğine işaret etmektedir.

Distopik bilim kurgu sinemasında kent ölçeğinde gözlemlenen mimari değişim ve dönüşümler bu bölümde 'Metropolis', 'The Fifth Element' ve 'Interstellar' filmleri kapsamında araştırılmış ve gelecek kent mekânları için mimari öngörülerin hangi yönde olduğunun izi sürülmüştür.

Bilim kurgu filmlerinin ilk ve en önemli temsilcilerinden olan 'Metropolis', Fritz Lang'in 1927 yılında yönetmenliğini yaptığı, fütüristik bir kentte geçen, işçi sınıfı ve yönetici sınıf arasındaki çatışmayı konu alan, ilk defa insan șeklinde bir makineyi yani robotu izleyici ile bulușturan, insani olanla mekânik olanı yan yana ele alan filmdir. Alman Dıșavurumcu tavrı benimsemiș olan film, kapitalist düzende yașanan sosyal krizleri ele almaktadır. Kapitalizm, işçilerin fabrikaya robotik bir şekilde giriş ve çıkışları gibi sahnelerle eleştirilmiş, sınıf ayrımı mekânsal bölümlemeler ile de vurgulanmıștır. İki sınıfın varlığının ele alındığı toplumda, işçi sınıfı yer altında yaşayan, makinelerden daha değersiz ve durmaksızın çalışmak zorunda olan sınıf, yönetici sınıfı ise yüksek yapılarda yaşayan, eğlence ve ihtişam odaklı zenginler sınıfı olarak betimlenmiştir.

Filmde hem mekânsal hem de sosyolojik katmanlardan oluşan hiyerarşinin odakta olduğu bir evren yaratılmıştır (Şekil 1). Film, teknolojik yeniliklerin yarattığı karmaşayı ön plana çıkarırken, zamansız toplumsal konuları eleștirmektedir. 'Metropolis' filminde yer alan kent, tarihi özellikleri yanında teknolojik eklemlenmeleri olan, büyük boyutlarda, çok katlı, yüksek, devasa modern yapıların altında varlığını 
sürdürmeye çalışan ve uzun zamandır orada bulunan yapılara referansta bulunmaktadırlar. Bu filmdeki kentte olduğu gibi bazı distopik bilim kurgu filmleri gelecekte, mevcut yapılaşmanın üzerine yeni teknolojilere göre eklentiler oluşturulacağını öngörmekteyken, özellikle son dönem bilim kurgu filmlerinde bu yaklaşım, yerini dijital dünyanın hâkim olduğu, tamamen baştan yaratılmış, temiz, net ve bütüncül yaklaşımla kurgulanmış kentlere bırakmıştır.



Şekil 1. Metropolis filminde kent (Metropolis, 1927).

'Metropolis' filmindeki kent, modernitenin ve teknolojik yeniliklerin domine ettiği ve yeniden yarattı̆̆ alanlar olmaktan çok geçmişle geleceğin kaotik birlikteliği ile çökmüş alanlar olarak tasvir edilmiştir. Harap ve yıkık bir kent tasvirinin, teknolojinin distopik yönünü göstermenin bir yolu olduğu düşünülmüştür.

Luc Besson tarafından yönetilen 1997 yılı yapımı 'The Fifth Element' filmi 1914 yılında uzaylıların bir Mısır tapınağına gelerek 5000 yılda bir ortaya çıkan büyük bir kötülüğü yenebilecek tek silahı güvende tutmak için götürmeleri ile başlar. Kötülüğ̈̈ yenebilecek tek silah, dört taş ve insan formundaki beşinci elementten oluşur. Ardından film, distopik bir geleceğin tasvir edildiği 2263 yılı New York'unda gelişen olaylar ile devam eder. Beşinci element olan Leeloo, bu kentte etrafında gördükleri karşısında dehşete düşerek kaçar ve filmin büyük bölümünü kentte başından geçen olaylar olușturur.

Filmde 2214 yılı New York'unun tasvirinde göze çarpan en belirgin özellik, başı ve sonu belirsiz kuleler, kuleler arasındaki dar alanlar ve bu alanlarda hareket eden uçan araçların oluşturduğu kaotik trafik aracılığıyla güçlü bir șekilde dikeyde tasarlanan kenttir (Şekil 2). Yüksek yapılara eklemlenmiş düşeyde ilerleyen raylı araçlar, bu yüksek yapılar arasında kalan devasa yükseklikteki derin boşluklar içinde üst üste oluşturulmuş ve katmanlaşmış uçan araç sokakları, kentin dramatik biçimde düşey hissedilmesine neden olmaktadır. Sobchack'ın (1997) belirttiği üzere birçok bilim kurgu filminde görülen kentsel hava ulaşımından farklı olarak, 'The Fifth Element' filminde, kent baş döndüren, yoğun bir șekilde katmanlaşmış yapılar labirenti olarak tasarlanmıştır. Bu kent, gökyüzü ve yeryüzünün artık görülemediği, düșeyde sınırları olmayan bir yerdir. Dünyanın en büyük sorunlarından biri olan insan nüfusunun gelecek yüzyıllarda daha da artmasıyla ulaşacağı boyutun mekânsal etkilerini içinde barındıran film, insanların Dünya dışında başka bir gezegen ya da uzayda yaşam arayışından hemen önceki zaman dilimini 
betimlemektedir. Filmde yeryüzünden kopuş, kentin uçsuz bucaksız yükseklikte tasarlanıp insanların toprakla temasının kesilmesiyle oluşturulmuştur. Filmde, insanlar için yakın bir gelecekte başka bir gezegen ya da uzayda bir mekân yaratılmasının gerekeceğinin ipuçları okunabilmektedir.

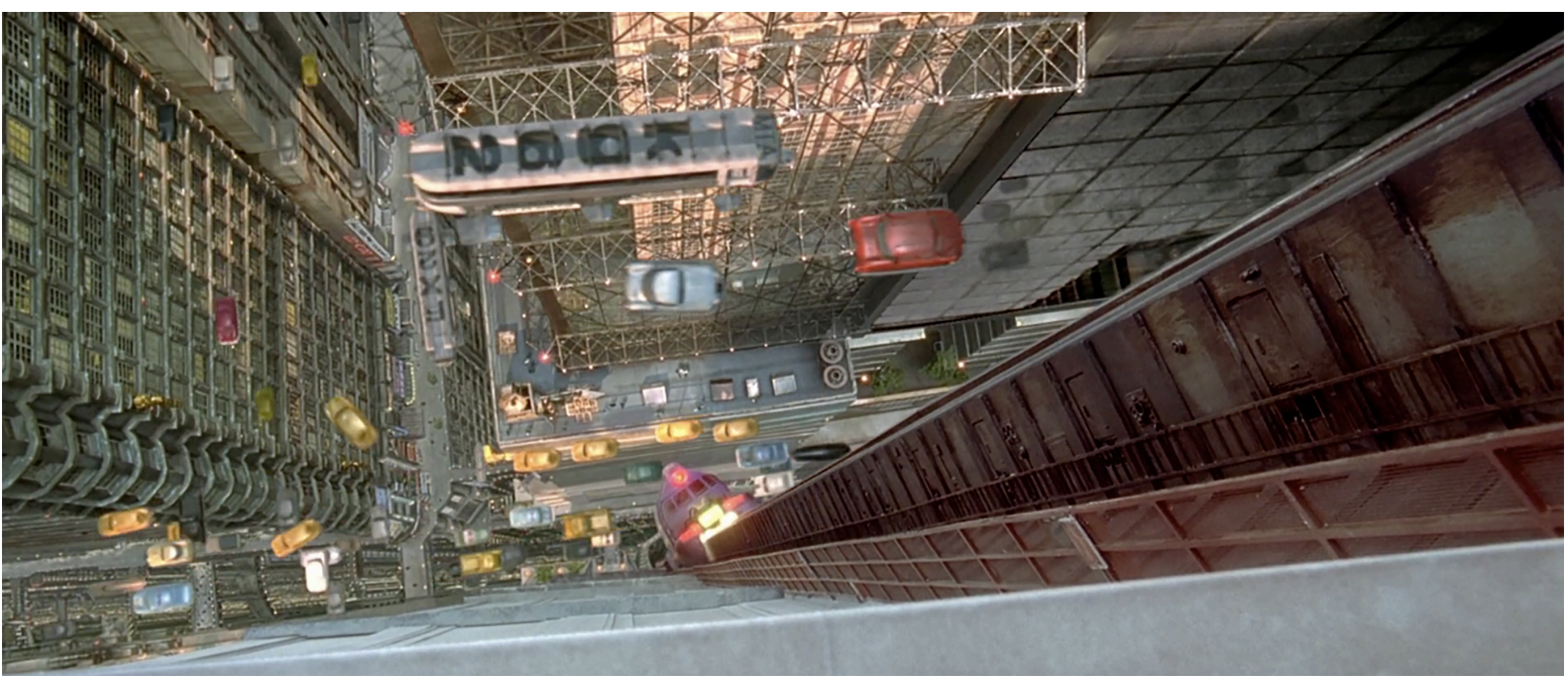

Şekil 2. The Fifth Element filminde kent (The Fifth Element, 1997).

'Interstellar', Christopher Nolan tarafından yönetilen 2014 yapımı, yakın gelecekte geçen, bir grup astronotun bir solucan deliğinden geçerek insanların yaşayabileceği yeni yer arayışlarını konu edinen bilim kurgu filmidir. Filmin distopyan yanı Dünya'nın çeşitli sebeplerden artık yaşanamayacak bir gezegen haline gelmesi fikridir. Filmin afişinde yer alan ve ana temanın anlatıldığı “Dünya'nın sonu, bizim sonumuz olmayacak" cümlesi hem bir çöküşü hem de insanların yeni arayışları olduğunu vurgulamaktadır.

Filmde artık yaşamın sürdürülmesinin imkânsızlaștığı bir gezegen haline gelen Dünya'ya alternatifler aranmaktadır. Bu arayışın sonunda kurgulanan 'yeni dünya', idealize edilmiş bir yaşam alanı olarak izleyicinin karşısına çıkmaktadır. Mekânın en belirgin özelliği uzayda bulunması nedeniyle yerçekiminin farklılaşması ve bu yüzden silindirik bir yapıda tasarlanan yüzeydir (Şekil 3). Cooper Station adlı bu uzay istasyonunun tasarımında, yerçekiminin manipüle edilerek birçok etkisinin dizginlenmesi gerektiği görülmektedir. Cooper Station'da insanların karşılaşabilecekleri sorunlar ve uzayda olmanın yol açtığı farklı fiziksel koșullara cevaplar bilim ve teknolojinin el verdiği ölçüde açıklığa kavuşturulurken, idealize kent kurgusundaki doğal alanlar da belirgin ölçüde dikkat çekmektedir. 'Interstellar'dan önceki, özellikle 90'lar bilim kurgu filmlerinde betimlenen köhne ve çöküşe geçmiş yeryüzünde bulunan katmanlı, karanlık ve kaotik kent dokusunun yerini yapılı doğanın hâkimiyetine bıraktığı görülmektedir. Mekânlar, henüz terkedilen Dünya'dakinin aksine insani ölçekte kurgulanırken, doğa-insan dengesini belirli ölçüde de olsa gözeterek sıfırdan yaratılan bu mekânda geleceğe dair öngörüler ve özlemler açıç̧a görülmektedir.

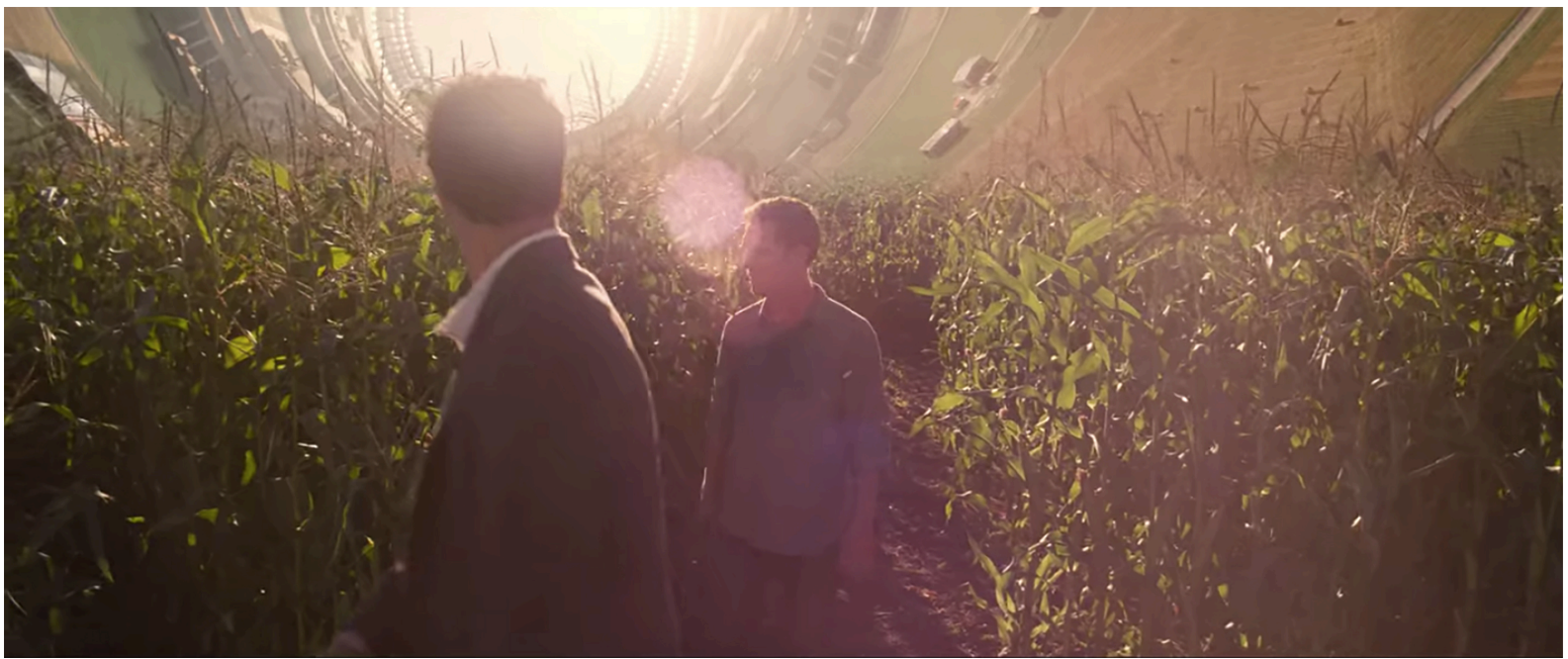

Şekil 3. Interstellar filminde kent (Interstellar, 2014). 
Distopik bilim kurgu filmlerinde görülen kent kurgularındaki ortak karakteristikler özetlenecek olunursa, yüksek yapılaşmanın vurgulanması, alternatif ulaşım sistemlerinin kent yaşamını biçimlendiren önemli bir unsur olarak öne çıkması, erken dönem bilim kurgu filmlerinde endüstrileşme ile birlikte gelen yeniliklerden kaynaklanan karmaşıklıklar ve çıkmazlar, son dönem eserlerinde ise özellikle bilgisayar teknolojilerinden ve dijitalleşmeden kaynaklanan yeniliğin neden olduğu tekinsizlik ve kuşku gözlemlenmektedir. Kent bugün hala toplumsal ve fiziksel ihtiyaçların reel mekânlarda karşılandığı, fiziksel anlamda işleyen, işlevlerini yerine getirebilmesi için bir arada bulunmak zorunda olan birimlere sahiptir. Fakat bu durumun bilim kurgu filmlerinde öngörüldüğü gibi teknolojik evrimin sonuçlarıyla birlikte değişmeye başladığı görülmektedir.

\subsection{Ev/Konut: İçinde Yaşanan Makine - Hücre}

Barınma ihtiyacının, hayatta kalma içgüdüsünün temel yansıması olduğu düşünüldüğünde 'konut ve/veya ev'in, insanların var olduğu ilk günlerden bu yana ilişki içinde oldukları en eski mekânlardan biri olduğu görülmektedir. İnsanların yaşadığı coğrafyaya hâkim olan kültür, zaman dilimi, toplumsal olaylar ve ekonomik şartlar gibi birçok etken yaşam biçimini oluşturmaktadır. Bu yaşam biçimi de en başta temel barınma alanları olmak üzere insanların yaşadıkları mekânların karakterine yansımaktadır.

Konut, salt fiziksel ve geometrik bir mekân anlayışla değil, toplumsal göstergeler, kişisel tercihler ve gündelik yaşam deneyimlerinin buluştuğu bir mekân olarak ele alınmalıdır. Bu nedenle, duyular ile sezilenden hareketle, evin hem kimlik oluşturan hem de bu kimliğin göstergesi konumunda olduğu söylenebilir (Dedeoğlu, 2005).

Konutu oluşturan olgular arasında içinde 'yașayan' en büyük etkendir. İnsan değiştikçe, mekân da değişir. İnsanı toplumsal olaylar, teknoloji, ekonomik koşullar, eğitim gibi değiştiren birçok etken bulunmaktadır. Bu noktada teknolojinin dünyadaki birçok alana olan etkisi, insana, dolayısıyla içinde yaşadığı ana mekâna yani konuta da yansımıștır.

Konutun distopik bilim kurgu sinemasındaki temsilleri, geleceğe dair mekânsal öngörülerin konuta/eve nasıl yansıdığı ve aynı ve/veya karşıt yönde gelişen öngörüler 'Brazil', 'Gattaca' filmleri ve 'Black Mirror Fifteen Million Merits' dizi bölümü aracılığıyla tespit edilmiştir.

Distopik bilim kurgu filmlerinde yer alan konutların mekânsal özelliklerinin incelenmesi amacıyla ele alınan ilk film olan 'Brazil', yönetmen Terry Gilliam'ın 1985 yılı yapımı, sanayileşme, terörizm, devlet kontrolü, bürokrasi, kaosa neden olan teknoloji, yara almış toplum gibi insanların ortak paydalarını oluşturan konular üzerine kurulmuş filmidir. Her şeyin tamamen devlet tarafından kontrol edildiği filmde, başkarakter, teknolojiden ve güçlü bürokrasiden kaçabileceği ve rüyalarındaki hayatı yaşayabileceği dünya hayali ile yaşamaktadır.

Filmde, endüstri sonrası toplumu bir kâbus atmosferinde tasvir edilerek insanların makineleşmeye karşı duydukları sorgusuz hayranlık hicvedilmiştir. Devasa yapılar ve hantal makinelerden oluşturulmuş, tek amacı işlevini yerine getirmek olan sistemin, aslında her parçasıyla kaosa neden olması eleştirilmektedir. Film izleyicinin gerçeklik algısında bir kırılma yaratmakta, gelecekte olabileceklere, teknolojinin gelişimine ve insanların yaşamındaki etkilerine değinmektedir. Filmdeki mekânlarda geçmiş ile gelecek aynı potada

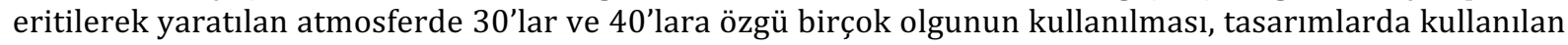
eklektik bileşkeler nedeniyle film anti-modernist bir kolaj olarak tanımlanabilmektedir (Tong, 2005, s. 54).

Filmin mekânları birçok yönüyle 'Metropolis' filmiyle benzerlik göstermektedir. 'Metropolis'te yer alan anıtsal ve devasa yapıların benzerleri 'Brazil'de de izleyici karşısına çıkmaktadır. 'Brazil'de kaotik ve belirsiz sistemin bir çarkı olan ana karakterin yaşadığı konut, içinde bulunduğu sistemin mekân ve insan bağlamındaki dışavurumu niteliğindedir. Filmde, endüstrileșme sonrası ütopya düşüncesini benimseyen, düzen ve katı kurallar sayesinde sorunların çözüleceğine inanan insanlara eleştirel bir yaklaşımda bulunulmuştur. Teknoloji ve makineleșme ile insanlara ve mekânlarına dayatılan bu katı tutumun sorunları çözmekten çok karmaşaya ve belirsizliğe neden olduğu yansıtılmıștır. Bunun en somut mekânsal yansıması da ana karakterin evinde duvarların içine gizlenmeye çalışılan fakat sürekli arızalanarak tamir edilen ama her defasında daha da kaotik bir hal alan denetim borularından oluşan tesisatlardır (Şekil 4). En küçük yaşam birimi olan evlerde olduğu kadar kentin her yanında farklı ölçeklerde var olan boru, makine parçaları, endüstriyel elemanlar ile makineleşme ve teknolojinin aşırı kullanımı eleştirilmektedir. 


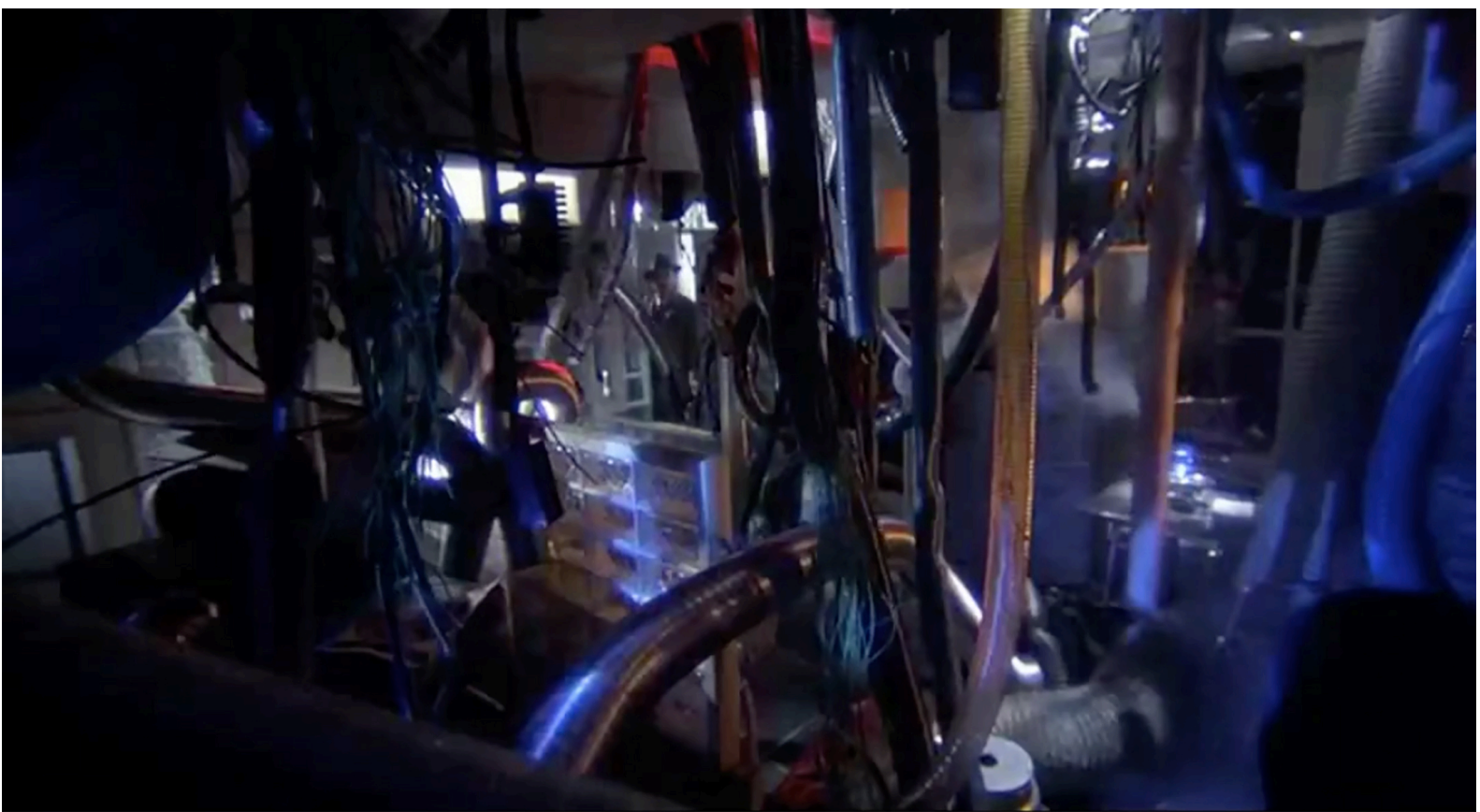

Şekil 4. Brazil filminde konut (Brazil, 1985).

Bilim kurgu filmlerinde yer alan konut betimlemelerini incelemek amacıyla ele alınan diğer bir örnek, 1997 yapımı 'Gattaca' filmidir. Andrew Niccol'un yönetmenliğini yaptığı filmin 21. yüzyılda geçen hikayesinde genetik mühendisliğinin geldiği nokta ve sonuçları kurgulanmıștır. Filmde genetik biliminin etkisi ile kusursuz insanlar üretilirken, üstün insan - normal insan ayrımı tekil bir örneğe odaklanılarak ele alınmıştır. Bilim ve teknolojinin yardımıyla özel görevler için üretilen üstün insanın yaşadığı ev, filmin mekânsal odaklarından biridir.

Filmin genelinde modernist bir mimari anlayış görülmektedir. Teknolojinin en büyük etkisinin genetik biliminde olduğu görülen filmde mekânlardaki yalınlık ve süsten arınmışlık göze çarpmaktadır (Şekil 5). Pallasmaa'nın (1995) düşüncesinde, evin, içinde yaşayanın kişiliği ve onun eşsiz yaşam izlerinin temsili olması durumu filmde açıç̧a görülmektedir. İnsanlar genetik biliminin geldiği nokta ile fizyolojik ve zihinsel olarak mükemmelleştirilirken toplumsal bağlamda ayrışmış ve yalnızlaşmıştır. Aynı şekilde bu insanların içinde yaşadıkları mekânlar da büyük boş alanları ile yaşanan mekân olmaktan uzak fiziksel ve geometrik bir yayılıma indirgenerek betimlenmiştir.

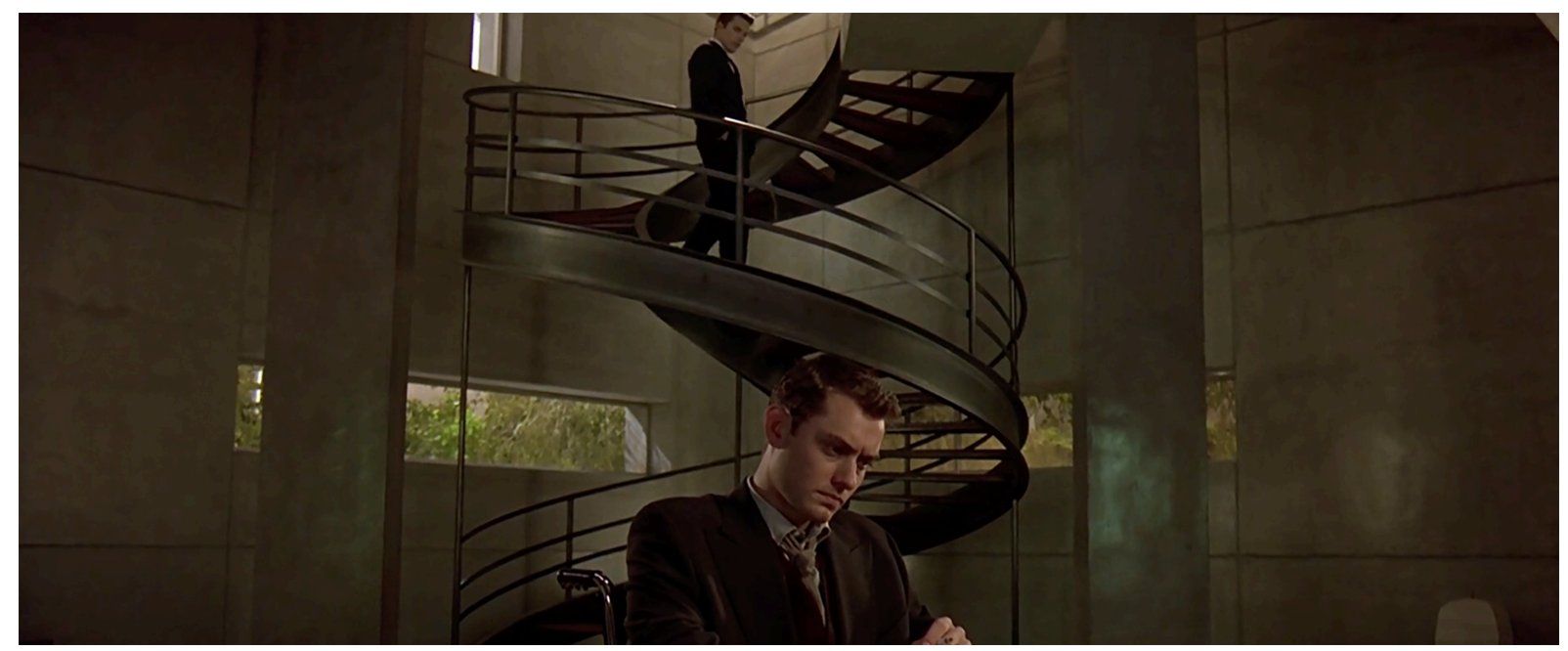

Şekil 5. Gattaca filminde konut (Gattaca, 1997). 


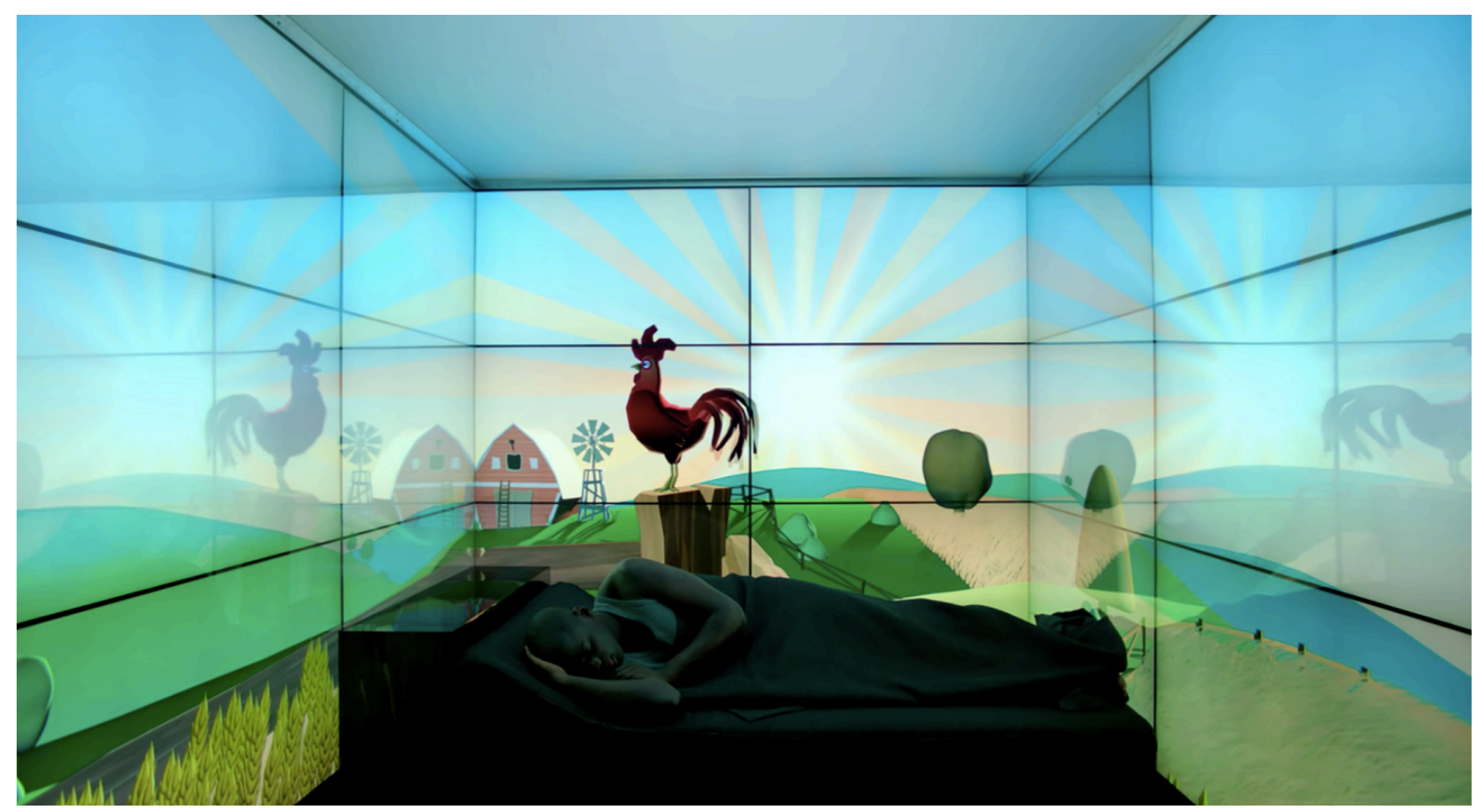

Şekil 6. Black Mirror - Fifteen Million Merits dizi bölümüde konut (Black Mirror, 2011).

Bu bölümde incelenen son örnek olan 'Black Mirror-Fifteen Million Merits', birçok distopik bilim kurgu filminin sıklıkla ele aldığı konu olan toplumun ve bireylerin sorunlarını, dijital teknolojinin getirdikleri ve götürdüklerini eleştirel bir tavırla ele almaktadır. Filmde üst sınıfın lüks içerisinde yaşaması ve medyanın hakimiyetinin devamı için gerekli enerjiyi üretmekle görevli alt sınıf, bisiklet pedalı çevirdikleri alan dışında, her gün mesai sonrası bireysel yaşam alanlarına çekilmektedirler. Teknolojinin etkilerinin yıkıcı olduğu alt sınıf yaşamına dair toplumsal ve bireysel öngörüleri işleyen filmde bireylerin yalnızlığı yaşadıkları mekânı da dönüştürmüş, konuta karşılık gelen mekânlar insanilikten uzak küçük hapishane hücrelerine benzer bir hal almıştır.

Film, evin nasıl tek bir hücreye dönüştüğünün göstergesidir. İçinde yaşayanın insan olduğuna dair hiçbir ipucunun olmayışı, sistemin baskısıyla sadece fiziksel güç ile çalışmaya ve medyanın baskısı ve egemenliği ile yaşamaya zorlanmaları insanların yaşadıkları mekâna doğrudan yansıtılmıştır. İnsanların, tek başlarına yaşadıkları bu evlerde sadece yatıp uzanabilecekleri bir yüzey ve tamamen dijital ekranlardan oluşan dört adet duvar bulunmaktadır (Şekil 6). Teknolojinin sağladığı hareket sensörleri sayesinde dokunsal olanı yok etmek ve sürekli gözetim altında bırakılmak, insanların yaşadıkları mekânları adeta gözün domine ettiği birer hapishane hücresine dönüştürmüştür. Kullanıcıya ait olan hiçbir kişisel nesnenin yaşanılan mekânda bulundurulmasına izin verilmemesi, insanların mekânsal belleğini meydana getiren anılar ve deneyimlerin oluşmasına engel olmuştur. Dolayısıyla mekân, içinde yaşayan insanla ilişkiye girememektedir. Mekânın tamamı dijitalleşme ile birlikte insanların yaşamına giren ekranlardan meydana gelmiş, yaşam ve mekân üç boyuttan iki boyuta indirgenmiştir. Ekranlar günlük yaşama dair deneyimlerin simülasyonlarını yansıtmaktadır. Uyanmak için bir doğa manzarası ve horoz ötüşünü iki boyutlu ve işitsel olarak deneyimleyen insanlar, çalışmadıkları kısa zaman diliminde zorunlu reklamlara ve televizyon programlarına maruz bırakılmaktadır. Sadece bir yatağın sığabileceği ölçülerden meydana gelen klostrofobik küplerde yaşamaya mahkûm bırakılan insanlar için ev artık duyumsanmanın, deneyimlenmenin, akışkan ve canlı olmanın ötesinde, otomatik, teknolojik, dijital ve tek tip hücrelere dönüşmüştür.

Distopik bilim kurgu filmlerindeki baskın değişkenin teknoloji oluşu, konutun mekânsal dönüşümü üzerinden açıkça okunabilmektedir. İnsanların dış dünyaya karşı kabukları niteliğinde olan evler özellikle teknolojik gelişmeler ve sosyal kopukluklar nedeniyle zırhlı birer kaleye dönüşmüștür. Bu bağlamda fiziksel anlamda da hücreye doğru evrilen konut, filmlerde mekânsal kurgular oluşturulurken distopyan tavrın en çok öne çıktığı mekânlardan biri olarak gözlemlenmiştir.

\subsection{Sosyal Alanlar: (A)Sosyalleşme - Yabancılaşma - Yalnızlaşma}

Çeşitli etkenler sebebiyle sürekli değişim halinde olan sosyal yaşam, 21. yüzyılda özellikle teknolojinin etkisiyle büyük bir değişim ve dönüşüm sürecine girmiştir. Bugünün sosyal yaşamına refere eden ve ana 
konularını geçmiş ve bugün üzerine temellendiren distopik bilim kurgu filmleri aracılığıyla sosyal yaşamın değişimi ve bu değişimin mekânsal yansımaları incelendiğinde özellikle teknolojinin etkisinin oldukça büyük olduğu görülmektedir.

Bu bölümde sosyal alanların geçirdiği mekânsal dönüşüm sonucu ortaya çlkan sosyal ağlar ve sanal mekânlar, 'The Island', 'Minority Report', 'Wall E' filmleri ele alınarak incelenmiștir.

Sosyal alanları incelemek amacıyla ele alınan ilk film olan 'The Island', 2005 yılında gösterime giren, yönetmenliğini Michael Bay'in yapmış olduğu, 21. yüzyılın ortalarında tıp ve teknolojideki gelişmeler ile sağlık sorunlarının büyük bir bölümünün klonlama teknolojisi yardımıyla çözüme kavuşturulduğu geleceğin tasvir edildiği bir filmdir. Filmde, Merrick Enstitüsü, toplumdan uzak bir bölgede, klonlama üzerinden kar sağlayan bir tesis kurmuştur. Gerçek dünyada yaşayan insanlar için ütopik bir gelecek tasvir edilse de üretilen klonların insanileșmesi onların tekinsiz distopyalarını oluşturmuștur.

İnsanlardan habersiz üretilen klonlar aslında birer organ olmaktan çok, gündelik yaşamlarını sürdüren bedenlerdir. Bu klonlar ekolojik sorunlar nedeniyle doğal dengesi bozulmuș olan diș dünyadan korunmak için içeride tutuldukları yalanına inandırılmıștır. Yer altında kurulan bu tesiste korunduklarına inandırılan klonların gündelik yaşamları da kurgulanmıştır. İçinde bulundukları durumu sorgulamamaları için hafızalarına müdahale ederek, iyilikleri düşünüldüğü sürekli empoze edilerek bir yaşam sürmeleri sağlanmaktadır. Bu yaşam gerçek dünyada devam eden hayatın ufak bir simülasyonu niteliğindedir. Dolayısıyla gündelik yaşam ritüellerinden toplumsal iletişime kadar tüm olgular kopyalanmıştır. Sosyalleşme olgusu da bunlardan biridir.

Filmde, insanların fiziksel olarak bir arada olabilmelerine rağmen teknolojik olanaklar ile temasın sıfıra indirilerek sosyalleştikleri görülmektedir. Filmde, boks maçı esnasında geçen bir sahne ile ele alınan sosyal yaşamın mekânsal yansıması da insanları görsel ve dokunsal anlamda bir arada kurgulayarak değil, dokunmatik yüzeyler ve hologramlar aracılığı ile oluşturulmuştur (Şekil 7). Sosyalleşme olgusunun özünde barındırdığı organik yapıyı kaybederek asosyalleşme yolunda evrilmeye başladığı gözlemlenmiştir.

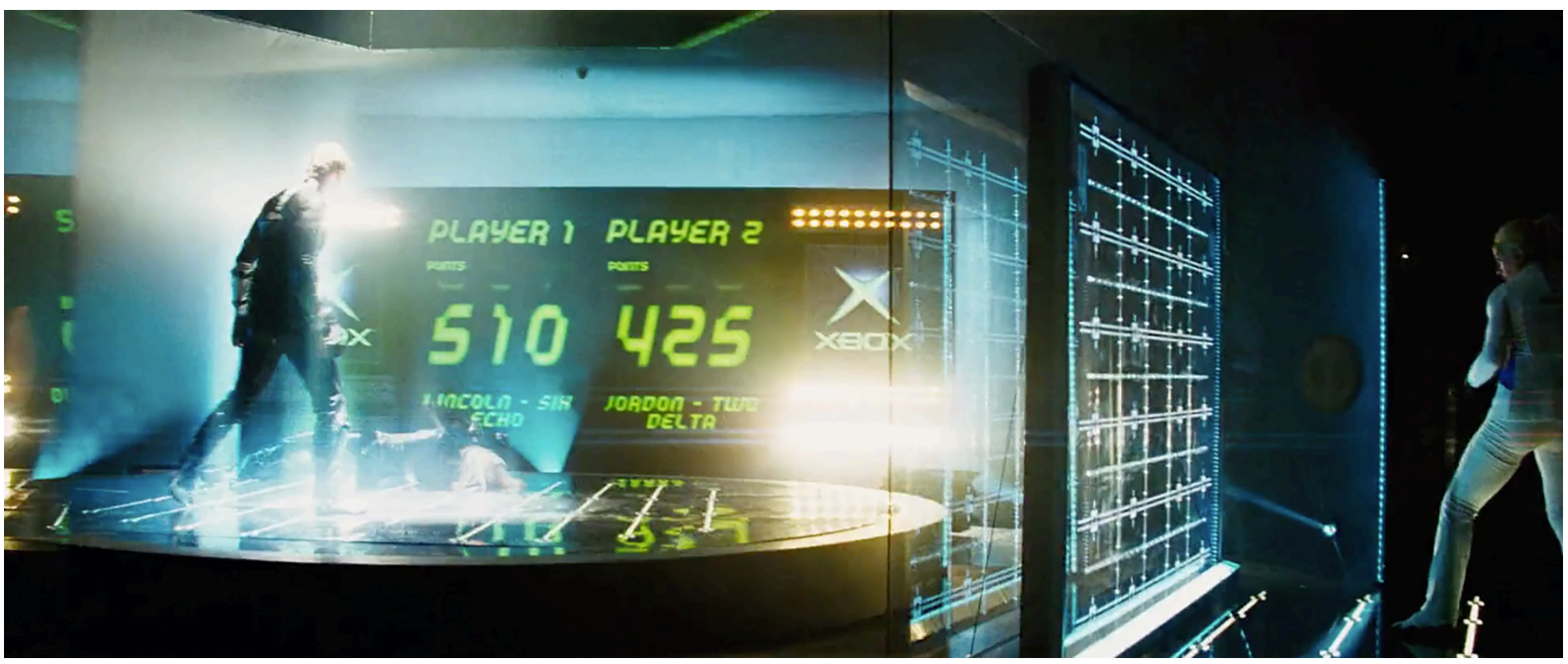

Şekil 7. The Island filminde sosyal alan (The Island, 2005)

İnsanlar arasındaki sosyal yaşamın başkalaştığının gözlemlendiği örneklerden ikincisi olan 'Minority Report', yönetmenliği Steven Spielberg tarafından yapılmış 2002 yılına ait bir filmdir. Önyargı kavramının adalet sistemi içerisindeki yerini kapitalizmin baskınlığındaki yaşam ve gözetim toplumunu betimleyerek anlatan film 2054 yılı Washington kentinde geçmektedir. Teknolojinin polisiye olaylara nasıl yansıdığını ele alan filmde dijital destek ve psişik güçlere sahip kahinler ile suçların önüne geçilmektedir. Böylece gelecekte işleneceği öngörülen cinayetler gerçekleşmeden kısa süre önce tespit edilerek engellenmektedir.

Filmdeki distopik unsurlar en çok toplumsal konularda göze çarpmaktadır. Gözetlenen toplum, bireyin paranoyaklaşması ve yabancılaşması, diğer insanlar ile arasındaki sosyal iletişimin kopması ve yalnızlaşması gibi sonuçlar doğurmuştur. Filmdeki mekânlar mevcut yapılaşma üzerine teknolojik eklemlemeler ile oluşturulmuştur. 
Filmde insanlar sanal bir sosyal mekân yaratılarak toplumda yer edindikleri simülasyonlarına yönlendirilmektedirler. Filmde insanlara toplumda arzu ettikleri yerlerde ve statülerde bulunma ve istedikleri kişiler ile istedikleri yollarla iletişime geçme imkânı sağlanmaktadır. Sosyal yaşamın sanal ve yanılsamadan ibaret olduğu görülen filmin bu sahneleri için kurgulanan mekânlar, kişilere özel küçük odalardan oluşmaktadır (Şekil 8). Bu odalar nötr, fiziksel özellikleri aynı ve sadece teknolojik gereksinimler doğrultusunda tasarlanmış küplerden oluşturulmuş ve bir koridorun iki yanında sıralanmıştır. Kullanıcıların hologramlar ile yaratılan simülasyon evreninde yeni bir kimlik yaratarak kendilerine yabancılaştıkları görülmektedir.

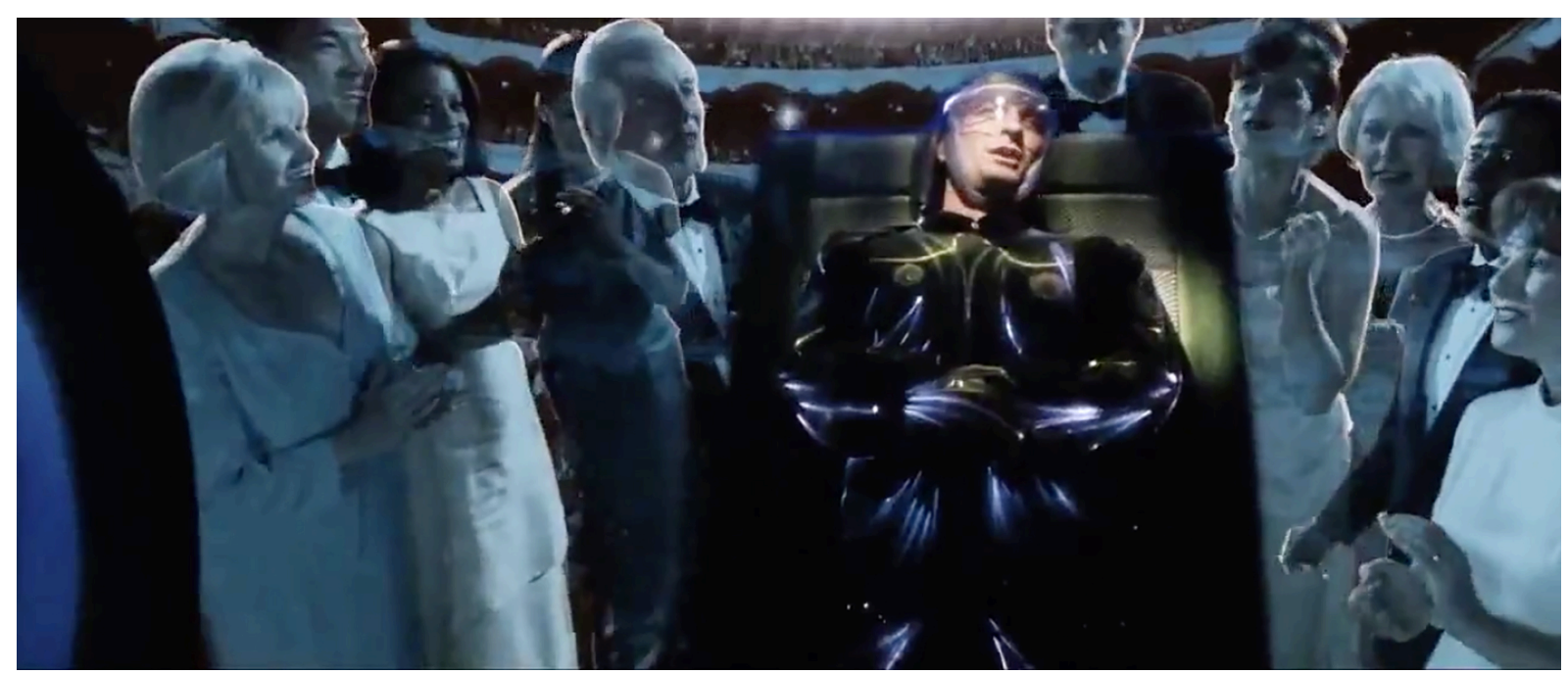

Şekil 8. Minority Report filminde sosyal alan (Minority Report, 2002).

Çalışma kapsamında incelenen filmler gibi günümüz sosyalleşme pratikleri ile benzerlik gösteren diğer bir örnek, Andrew Stanton yönetmenliğinde 2008 yılında gösterime girmiş olan 'Wall E' adlı animasyon filmdir. Hikâye, çevre kirliliği, doğal kaynakların aşırı ve bilinçsiz tüketimi nedeniyle yaşanamaz duruma gelen Dünya'dan ayrılmak zorunda kalan insanların bir uzay gemisinde oluşturdukları yeni yaşam etrafında şekillenmektedir. İki robot arasındaki romantik ilişki etrafında kurgulanan distopik gelecekte insanların sevgi ve aşk gibi duygulardan uzaklaşması ile oluşan zıtlık filmin özünü oluşturmaktadır.

Filmin hikâyesi iki ana bölümden oluşmaktadır. Birincisi insanların tüm kaynaklarını tükettikten sonra bir çöp yığını haline gelen ve artık üzerinde yaşayan hiçbir canlının kalmadığı Dünya'da Wall E'nin yalnız yaşamı, diğeri ise insanların Dünya'yı terk ettikten sonra yeni yaşamlarını yeniden kurdukları Axiom adlı uzay gemisindeki hayattır. Uzay gemisindeki yaşam, insanların kendilerine hizmet eden teknolojik öğeler ile her türlü ihtiyaçlarının karşılanması, hareketsizliklerinin nedeni olan yeni yaşam şekilleri ile aşırı kilolu canlılara dönüşmesi gibi sonuçlar doğurmuştur. Filmde sosyal anlamda gözlemlenen en büyük özellik ise insanların birbirlerine ve içinde bulundukları mekâna yabancılaşmaları sonucu yalnızlaşmalarıdır. Bu yalnızlaşmanın en büyük nedeni ise teknoloji baskınlığı ile oluşan sosyal iletişimsizliktir. Bahsedilen teknolojik yalnızlık filmin geneline hâkim olan konu olarak büyük bir önem taşımaktadır. Yabancılaşma gitgide artmış ve insanlar kendi dünyaları içerisinde kaybolmuştur. İnsanların bu durumdan kurtulabilmesi için yapılması gereken, bilinçaltlarında yer alan özgürleşme isteklerini açığa çıkaracak bir farkındalık yaratmaktır. Bu farkındalığın somutlaşmış temsili de, Dünya'da kalan küçük bitkidir (Güngör, 2015, s. 12).

Filmde sosyalleşmenin sanal ve dijital bir yol üzerinden gerçekleşmesi, günümüz sosyal medya kullanımı ile paralellik göstermektedir. Filmde eleştirel yaklaşımla ele alınan bu durum, insanların fiziksel olarak yan yana olmalarına rağmen ekranlar aracılığı ile iletişim kurmaları ile hicvedilmiştir (Şekil 9). Birbirlerine bakmamaları, fiziksel bağın kopuşu ve sayıca kalabalık olunmasına rağmen gözlemlenen yalnızlaşma olgusu ile sosyalleşme için gerekli olan fiziksel mekân gereksinimi de ortadan kaldırılmıştır. Bu durum internet ağları yoluyla sosyalleşme sonucu ortaya çıkan 'sibermekân' kavramını doğurmaktadır.

Ticaret, eğitim, eğlence, cinsellik, sosyalleşme gibi fiziksel mekândaki işlevlerin giderek sanal mekândaki işlevlerle yer değiştirdiği bu çağda, sanal gerçeklik deneyimi aracılığıyla gerçek topluluklar yaratarak yeniden inşa edilen ve bitlerden oluşan sibermekân, internetin dijital destekli bilgi mekânı ve birbirine bağlı bilgisayar ağlarının ortamıdır (Mitchell, 1995). 


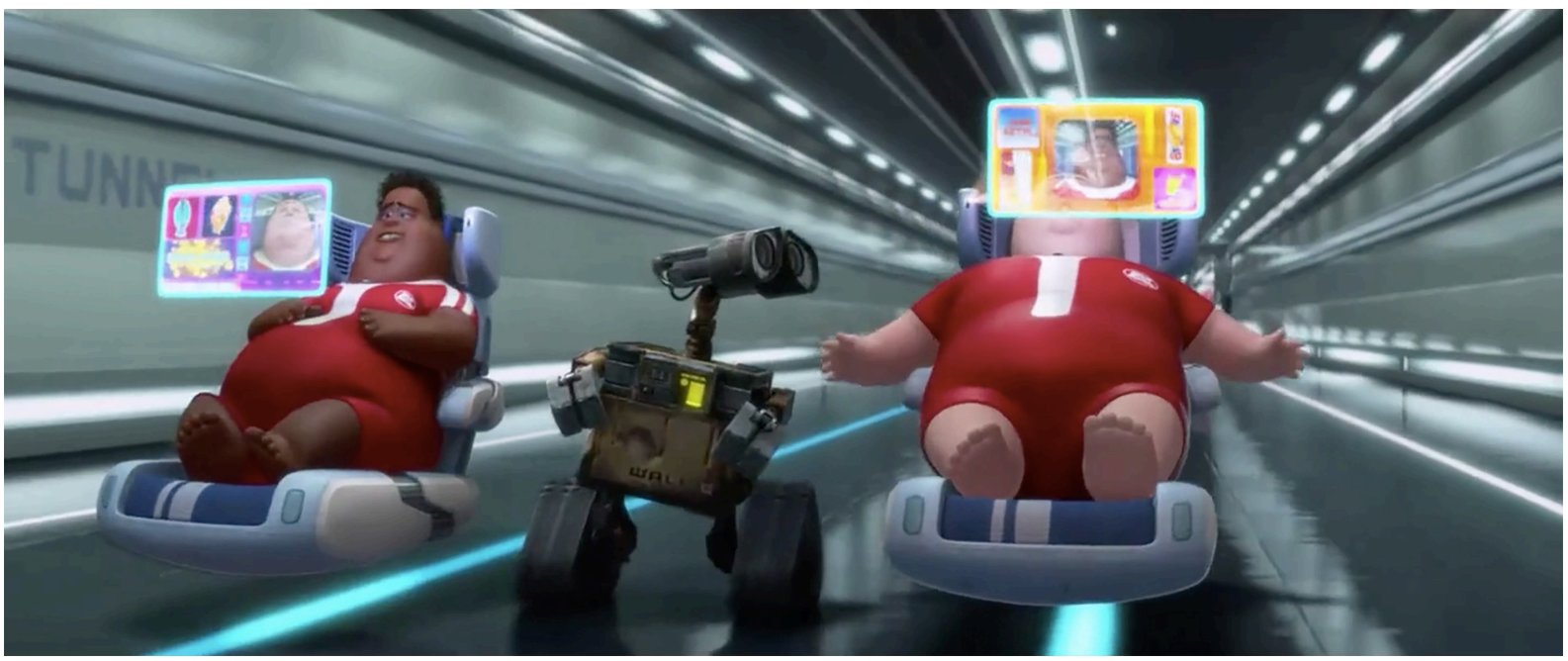

Şekil 9. Wall E filminde sosyal alan (Wall E, 2008).

Sosyalleşme mekânlarının evrimi sonucu vardığı bu noktada gereksinim duyulmayan fiziksel mekânın yok oluşu sonucu insanların arasındaki fiziksel bağın koptuğu görülmektedir. Bu bağın kopuşu ile sosyal yaşamın tanımının ve yönteminin değiştiği, insanların bireyselliklerini daha da ön plana çıkarmalarına neden olduğu görülmektedir.

Sosyal iletişim teknolojilerinin gelişimi ve sibermekânın ortaya çıkışı ile küreselleşmenin önündeki engellerin yok olduğunu belirten Harvey'e (1999) göre; zaman ve mekân kavramları önemini yitirmiş, iletişim anlık olarak gerçekleşmeye başlamıştır. Bu durum zamanda sıkışmaya neden olurken, bireylerin çevreleriyle ve dünyayla kurdukları iletişim, alıșkanlıklar, düșünceler ve duyguların değişimine sebep olmuş, sanal yaşam, sanal davranış ve sanal kültür olarak adlandırılan kavramlar ortaya çıkmıștır. Bu bağlamda sosyal yaşamda meydana gelen değişimler, bireyleri yalnızlığa sürükleyerek, yabancılaşma ve yalnızlaşma sürecine götürmektedir.

Modern toplumların birincil sorunu haline gelen zaman sınırıllı̆̆ sebebiyle sanal paylașım ağlarından olușan sibermekânların bireylerin yeni sosyalleșme biçimleri için en uygun mekânlar olduğu düşünülmektedir. Fakat distopik bilim kurgu filmlerinin çoğunda insanların sanal yollar aracılığıyla sosyalleşmesi, teknoloji ve toplum arasındaki ilişki bağlamında eleştirel bir bakış açısıyla ele alınmaktadır (Ünver, 2016, s. 66). Filmlerde teknoloji karşısında edilgenleşen insan modelinin ortaya çıktığı ve insanlar arasındaki bağın kopmaya başladığı öngörülmektedir.

\subsection{Ticari Mekânlar: Tüket - Daha Çok Tüket - Yok Et}

İnsanların en temel eylemlerinden biri olan alışverişin geçmişi ve geleceği, bir bakıma toplumsal yaşamın, kentlerin ve teknolojinin gelişiminin tarihi niteliğindedir. Ticaretin zaman içinde değişen eylem biçimi ve anlamı, eylemin gerçekleştiği mekânları da etkilemiștir.

Alışveriş eyleminin mekânsal bağlamda değişimi, agoralar, pazar yerleri ve hanların ardından endüstrileşme sonrasındaki ekonomik, sosyal değişimler ve kapitalizmin gelişimiyle birlikte 19. yüzyılda pasajlar ve arkadlarla devam etmiş ve sonunda devasa büyüklükteki parıltılı ve gösterişli alışveriş merkezlerine dönüşmüștür (Vural, 2005).

20. yüzyıla gelindiğinde ise, kapitalizmin yalnızca üretim ve tüketim ilişkilerini düzenleyen bir ekonomik sistem olmaktan çok, gündelik yaşamı düzenleyen kültürel bir gerçeklik haline geldiği görülmüsstür. Tüketimin yaşamsal ihtiyaçların karşılanması işlevinden daha öte bir kimlik tarifleme aracına dönüşmesi sonucunda gündelik yaşamın her alanı, tüketim eylemiyle kuşatılmıștır. 20. yüzyılda kamusal ilișkinin ve kamusal mekânın anlamı da önemli bir dönüşüm geçirmektedir (Baudrillard, 1997).

Distopik bilim kurgu filmlerindeki tüketim olgusu bağlamında gözlemlenebilen ortak bilinç, tüketimin sürekli artan bir ivmeyle yükselişidir. Filmlerde tüketimin, alışveriş nesnelerinden, doğal kaynaklara kadar yaşamın her alanında bulunduğu görülmektedir. Teknoloji, tüketimi besleyen bir olgu olarak kullanılmıș ve sonunda önüne geçilemez bir hal almıştır. Bu yaklaşım alışveriş eyleminin gerçekleştiği mekânlara da yansımış ve mekânları dönüştürmüştür. 
Ticari mekânların değișen tüketim pratikleri ve teknoloji ile birlikte mekânsal bağlamda geçirdiği başkalaşım, 'Ghost in the Shell', 'Minority Report' ve 'Wall E' filmleri üzerinden incelenmiştir.

İncelenen ilk örnek olan 'Ghost in the Shell', Masamune Shirow tarafından yaratılan mangalar esas alınarak 1995 yılında filmleștirilmiş, Kazunori İto tarafından yazılmış ve Mamoru Oshii tarafından yönetilmiş bir animedir. Siberpunk türünün ilk klasik örneklerinden sayılan film, insanların makinelerle nasıl iletișime geçtiği sorusu üzerine kurulmuş bir hikâyeye sahiptir. Film, biyolojik ve yapay (elektronik, mekânik, robotik) kısımları olan varlıklar olan 'siborg'ların (cyborg) doğasını keşfetmeye çalışan, siborgların ve insan olmanın ne olduğunu derinlemesine sorgulayan hümanist bir filmdir. Filmde, hümanizmin içerdiği insan mükemmelliği, ilerleme, kontrol, dünyanın rasyonelliği gibi kavramları sorgulanmaktadır (Nozaki, Oshii ve Shirow, 1995).

Filmdeki yapılaşmada göze çarpan en önemli özellik kaotik yaşamın dışavurumudur. Geleceğin kenti çöküş ve bozulmuş yapısıyla tasvir edilmektedir. Kent dokusu eklektik bir anlayış benimsenerek eski yapılar üzerine yeninin eklemlenmesi ile karmaşık bir hal almıştır. Modern kent fikri, postmodern eleştiri ile ele alınmaktadır. Alışveriş mekânları çoğu distopik bilim kurgunun ana teması olan toplumsal sınıf ayrımını yansıtmaktadır. Yaşamın karmaşıklığı, düzensizliği ve köhneliğinin yansıtıldığı bu alışveriş mekânı, düşük gelirli halkın yaşadığı konutlarla çevrelenmiştir.

Filmde alışveriş eyleminin gerçekleştiği mekânları betimlemek için eski yapılar kullanılmıştır (Şekil 10). Bu yapılaşma kendi içinde bir düzen barındırsa da kaos kavramını yansıtacak şekilde kurgulanmıştır. Geleceğin ticari mekânları çökmekte olan bozulmuş kent ve toplumsal yapıyla paralellikler göstermektedir. Mekânlarda eklektik bir tasarım anlayıșı benimsenen distopik hikâyede vurgulanan kavramın 'karmaşa' olduğu yansıtılmıştır. Tüketimin yıkıcı ve yok edici etkisi tüm mekânlarda olduğu gibi alışveriş eyleminin gerçekleştiği mekânlarda da görülmektedir.

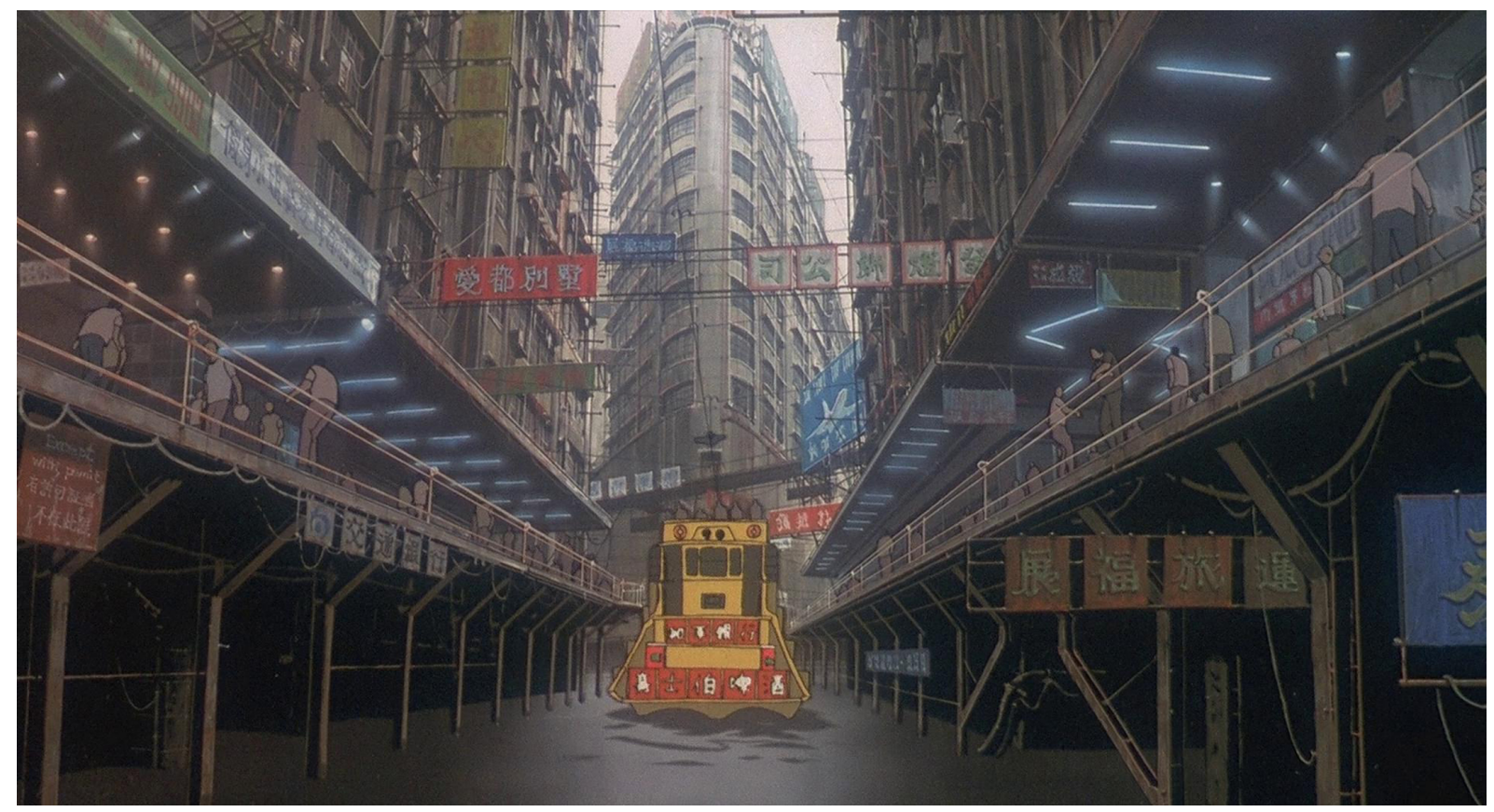

Şekil 10. Ghost in the Shell filminde ticari mekânlar (Ghost in the Shell, 1995).

Alışveriş mekânlarının ele alındığı diğer bir film olan 'Minority Report', teknolojinin tüketim üzerindeki etkilerinin daha fazla görülmeye başlandığı filmlerden biridir. Filmde yer alan mekânlar, var olan mekânlara yapılan teknolojik eklemlenmelerle oluşturulmuştur. Ütopik tasvirlerin yanında teknoloji yoluyla oluşturulan dünyanın aslında distopik bir geleceğe doğru ilerlediği görülmektedir. Steven Spielberg filmde ışıl ışıl bir gelecek tablosu çizerken o parlak geleceğin ardında yatan pisliği de göstermektedir (Kutlu, 2004). Filmde oluşturulan bu distopik tavır mekânlarda özellikle gözetlenen toplum olgusunu destekleyici unsur olarak kullanılmıştır. Göz tanımlaması yapan kapılar, etkileşimli gazete ve dergiler, uçan polis araçları gibi fütüristik taşıtlar filmdeki mekân ve ürün tasarımlarına örneklerdir.

Gözetlenen toplum üzerinde oluşturulan en büyük algı yönetimi alışveriş eylemi üzerinedir. Gücü ve teknolojiyi ellerinde tutan dev şirketler, insanların kişisel bilgilerine ulaşarak sokakta yürürken dahi kişiye özel reklamlar gösterebilmektedir. Ulusal güvenlik, adalet sistemi, gözetim ve denetim sistemleri ve 
insanları tüketime yönlendirme biçimleri üzerine eleştiri niteliğinde olan filmin geneline yayılmış bir alışveriş teması mevcuttur. 1977 yılında yapımı tamamlanmış bir alışveriş merkezi olan 'Hawthorne Plaza Shopping Center' yapısı teknolojik eklemlemeler ile filmde kullanılmıştır (Şekil 11).

Filmde insanların gözetimi teknoloji desteği ile birlikte üst boyutlara ulaşmıştır. Özel şirketlerin insan hayatları üzerindeki aşırı kontrolleri dikkat çekmektedir. Kişilerin zihinleri sürekli olarak ticari odaklı reklamlara maruz kalmaktadır. Her yerde, her şekilde mevcut olan devasa ekranlar retina tarayıcıları ile ortak çalışmakta ve yayın alanına giren potansiyel müşterilerin kimlik bilgilerini analiz etmekte, adlarına özel çağrılarda bulunmaktadırlar. Filmde bulunan alışveriş eylemine eklemlenmiş teknolojik uygulamalardan bir diğeri de insanların veritabanlarından elde edilen bilgiler doğrultusunda tüketimi artırmaya yönelik bir uygulamadır.

Alışveriş merkezinde yer alan bir giyim mağazasında, müşterilerin daha önce yapmış oldukları alışverişlerde aldıkları ürünler sıralanarak bir veritabanı oluşturulmakta ve bu bilgiler müşterinin mağazaya tekrar geldiğinde yönlendirilmesi sağlanmaktadır. Bu yönlendirme ise müşterinin karşısına çıkan hologram sayesinde birebir ilişkinin simule edilmesi yoluyla gerçekleştirilmektedir.

Mevcut bir alışveriş merkezine yapılan bu teknolojik eklemlemeler sonucu mekânın kimliği yadsınamaz ölçüde değişikliğe uğramıştır. Mekânın her yerinde hologramlar ve sürekli değişen görüntüler mevcuttur. Görüntülerin aktarılması için gereken ekranlar duvarlar, yatay ve dikey yüzeylerin tamamını kaplamış, mekânı ışıklı, oldukça hareketli, dinamik ve yorucu bir mekân haline getirmiștir. Filmde yer alan alışveriş merkezi tüketimin eyleminin teknolojik ve dijital destekle mekânı nasıl dönüștürdüğünün örneğidir.

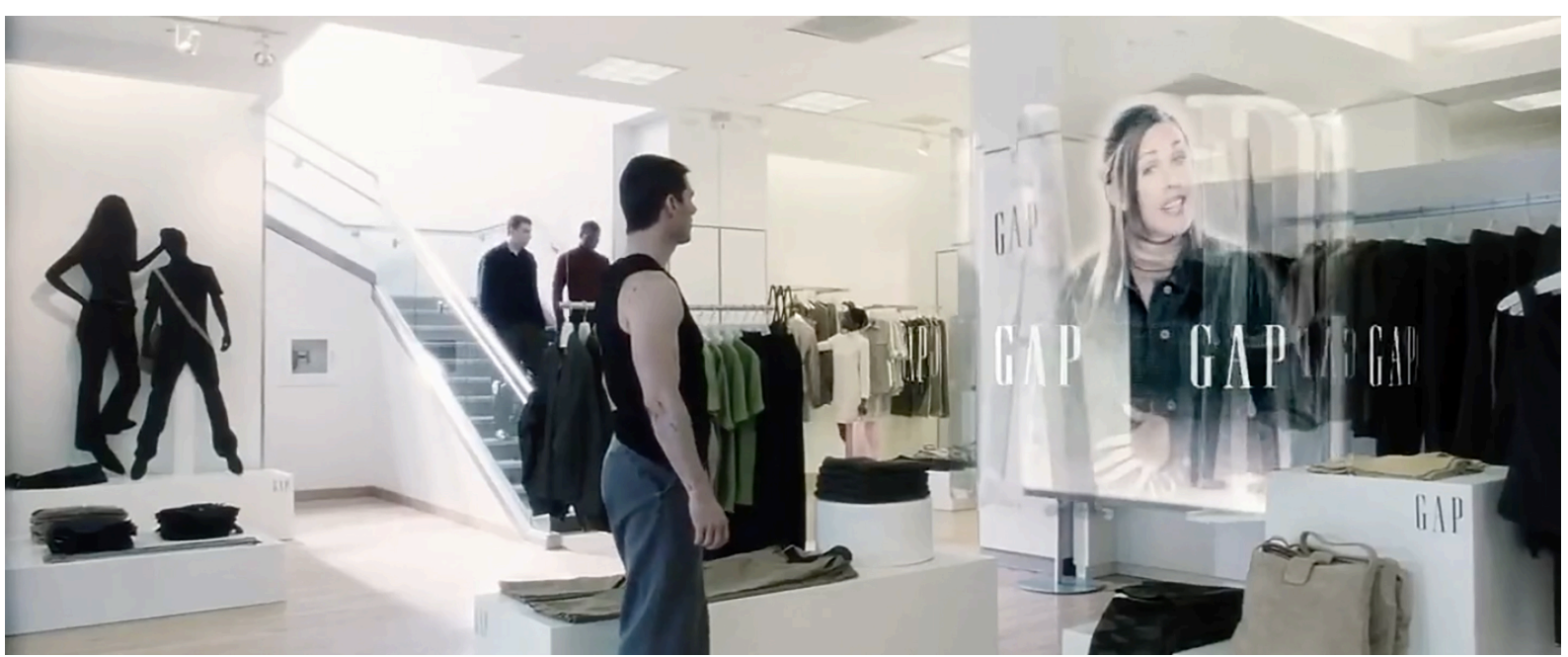

Şekil 11. Minority Report filminde ticari mekânlar (Minority Report, 2002).

İncelenen bir diğer film olan 'Wall E', teknoloji dominasyonunun en üst düzeyde hissedildiği distopik bilim kurgu örneklerinden biridir. Filmin alışveriş eylemi ile ilişkisi birçok distopik bilimkurgu hikayesinde karşılaşılan 'tüketim' olgusunun aşırılaşması ve insanların yok eden konumuna gelmesi ile oluşturulmuştur. İnsanların doğayı tüketmeleri sonucu yaşadıkları gezegenden dahi vazgeçmek zorunda kaldıkları filmde, yerleștikleri uzay gemisini inşa eden mega şirketin adının 'BnL' (Buy and Large) olması tüketim olgusuna vurgu yapmaktadır.

Yaşama dair her şeyin dayatıldığı ve sorgulanmadığı uzay gemisinde insanların yiyecekleri, giyecekleri, alacakları eğitim, gidecekleri yol, her șey programlanmıștır. Tüketim de bu dayatılan öğelerin başında gelmektedir. İnsanların kıyafetleri üzerinden verilebilecek örnekte artık kırmızı giymemeleri, mavi rengin daha iyi olduğu hem sesli hem de mekân içerisinde oluşturulmuş dev hologramlar ile insanlara empoze edilmektedir.

Filmde insanlara dayatılan tüketim, uzay gemisinde tek bir alışveriş mekânı ile var olmaktan çok, tüm mekâna nüfus etmiştir. İnsanların günlerini geçirdikleri uzay gemisinin ana mekânında her yer alışverişi vurgulayan hologramlar ve ekranlarla donatılmıștır. Sesli uyarılar ile desteklenen bu reklamlar 'ye, satın al, yaşa' gibi mesajlar içermektedir. İnsanlar aşırı kiloları ve tembellikleri nedeniyle hiçbir eylem için oturmuş oldukları uçan koltuklardan kalkamamaktadırlar. Dolayısıyla yapmış oldukları alışveriş için de herhangi bir yere gitmeleri gerekmemekte, satın almış oldukları ürün onların bulunduğu yere gelmektedir. Filmde alışveriş hayatın her dakikasına ve her mekâna yayılmış durumdadır. 
Yok edilen Dünya üzerindeki mevcut mekânların kullanımının imkânsız olması nedeniyle kurgulanan yeni yaşam alanında teknolojinin mutlak hâkimiyeti görülmektedir (Şekil 12). Tüketim, artık sadece fiziksel mekânda gerçekleștirilen bir eylem olmaktan çıkmış, yaşamın her anına ve alanına sinmiştir. Dolayısıyla bu örnekte incelenen ticari mekânlar, özünde belirli bir mekân analizinden çok, alışverişin yaşama dâhil olduğu anların mekânsal yansımaları bağlamında gerçekleștirilmiştir. Alışılagelmiş alışveriş pratiklerinde kullanıcıların belirli bir fiziksel mekâna gitmeleri, filmde ürünün kullanıcının olduğu yere gelmesi yönünde olmuştur. Bu nedenle filmde alışveriş mekânlarının fiziksel boyutta yok olmaya başladığı gözlemlenmektedir.

Filmler üzerinden yapılan incelemeler sonucu ticari eylemler için kurgulanmış olan mekânların fiziksel boyuttan sanal boyuta doğru evrimleşen bir süreç içerisinde oldukları görülmektedir. Erken dönem bilim kurgu filmlerinde eski yapılar üzerine eklemlenen teknolojik unsurlar, olanakların çoğalması ile daha baskın hale gelmiş ve sonunda tamamen teknolojinin egemen olmasıyla fiziksel olarak yok olmaya başlamışlardır.

Tüketimin hızla artışı fakat alışveriş eylemi için fiziksel mekân gereksiniminin azalması ve yok olması, ilkin ters orantılı olarak algılanabilmektedir. Bu noktada teknolojinin olanakları devreye girmekte ve fiziksel mekândan sibermekâna doğru bir dönüşüm başlamaktadır. Filmlerde, sanal ve dijital olana evrilen alışveriş̧ mekânlarının dönüşümünün, tüketimin daha çok tüketime ardından da yok etmeye odaklı hale geldiği, mekânların da bu dönüşümden büyük oranda etkilendiği öngörülmüştür.

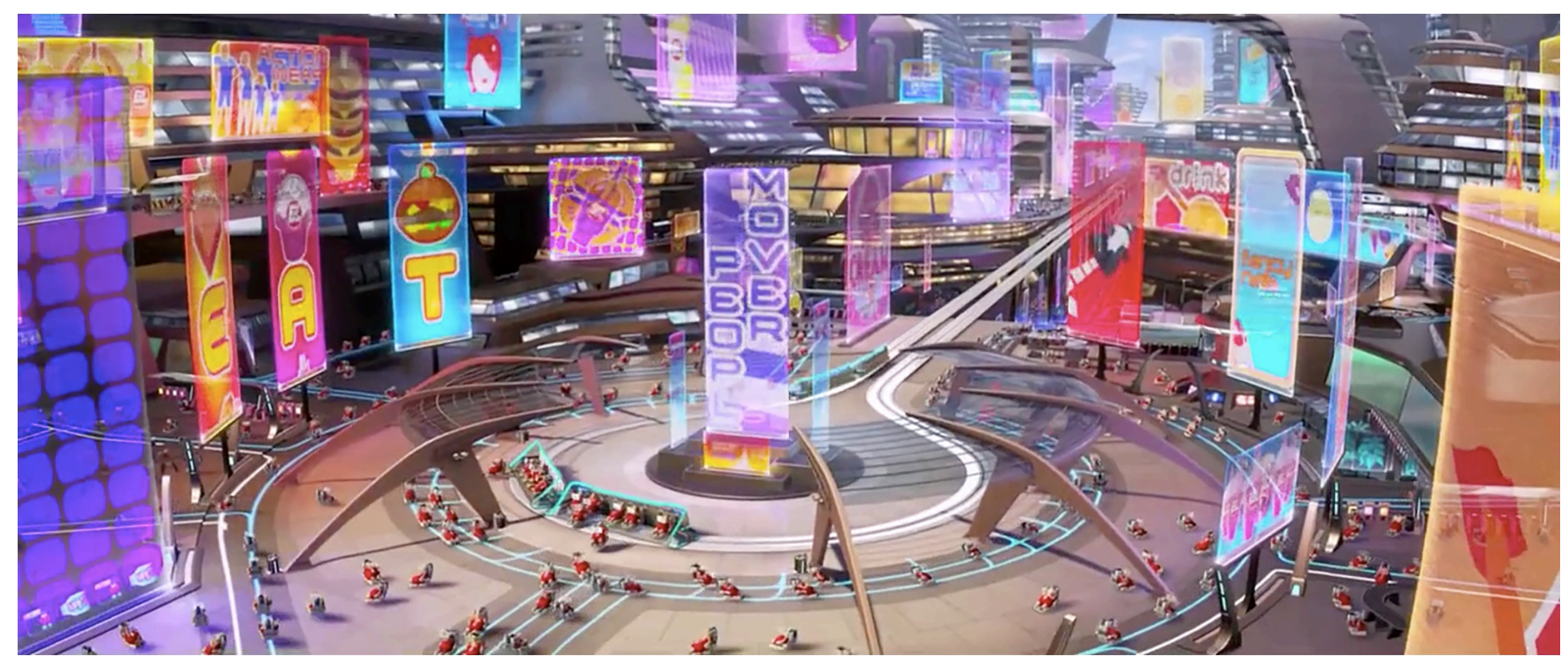

Şekil 12. Wall E filminde ticari mekânlar (Wall E, 2008).

\section{Sonuç}

Teknoloji ve bilgi çağının etkisiyle mimarlık ve mekân kavramları çarpıcı bir değişiklik döneminden geçmekte ve mekân kavramı dönüşüp başkalaşmaktadır. Mekân, tarih boyunca birçok fiziksel değişime uğrarken teknolojinin baskınlığı ve dijital etkiler ile fiziksel bir varlıktan sanal bir oluşuma dönüşmeye başlamıştır. Bu durum birçok farklı disiplinde olduğu gibi mimarlık için de tanımlar ve gerçeklik algısı üzerinde değişimler yaratmıştır.

Disiplinlerarası yaklaşımın benimsendiği çalışmada, teknolojinin etkilerine sinema perspektifinden bakılarak mekânın geçirdiği fiziksel ve kavramsal dönüşüm gözler önüne serilmiştir. Gelecek mekânları için sorulabilecek olası sorulara, gelecek kurgularından oluşan bilim kurgu filmleri aracılığıly cevap aranmıştır. Bilim kurgu sineması ile ilgili yapılan araştırma sonucunda filmlerin çok büyük bir kısmının pesimist yaklaşımla kurgulandığı görülmüştür. İnsanlar teknolojik gelişim ve dijital dünyanın varoluşu karşısında endişelenerek, eleştirel ve kötümser bir yaklaşımla 'distopik' gelecekler kurgulamışlardır.

Çoğunlukla eskinin alışılmıș ve tanıdık olması nedeniyle verdiği güven hissi, eski ve bilineni yeni olana tercih etme eğilimine neden olmaktadır. Yeni olandan ise bilinmez, şaşırtıcı ve kimi zaman da tekinsiz oluşu nedeniyle uzak durulmuştur. Gelecek ise varoluşu gereği yeni olanı içinde barındırdığından dolayı insanların temkinli yaklaştığı bir olgudur. Geleceğin bilinmezliği yeni olana karşı güvensizlik ve endişe duyulmasına neden olmaktadır. Bu sebeple, gelecek öngörülerinden oluşan bilim kurgu filmlerindeki genel yaklaşımın kötümser ve eleştirel oluşu anlaşılabilir bir durumdur. Bu yaklaşımla oluşturulan distopyalar, 
bugünün teknolojik, toplumsal, siyasi ve bilimsel çıkmazlarından yola çıkılarak tasarlanan eleştirilerdir. Bilim kurgu sinemasında distopik yaklașım hâkimiyetinin nedeni yeni olana karşı duyulan bu güvensizlik ve endişedir. Gelecekteki olası sorunların öngörülmesi, anlaşılması ve çözülmesi de yeni olanın ve geleceğin daha güvenilir ve tanıdık olmasının sağlanmasına olanak tanımaktadır. Bu bağlamda çalışma kapsamında mimarlığın ve mekân kavramının geleceği ile ilgili sorulara disiplinlerarası yöntemle mimarlık-sinema arakesitinde cevap aranmıştır.

Mimarlık kuramının gelişimi adına eleştirel bakış açısı ile incelenen filmler, kentlerin, yapıların, iç mekânların, kültürlerin ve yaşam şekillerinin farklı yönetmenler tarafından oluşturulmuş görüntülerini izleyiciye sunmaktadır. Filmler için kurgulanan mimari projeler, gelecek mekânlarına, kentsel dönüşüme, toplumsal gelişime yönelik farklı bakış açıları ve öneriler sunmaktadır. Sinema, çoğu zaman toplumsal bilinci şekillendirerek mimarlığın ve tasarımın birçok alanına önemli katkılar sağlamaktadır.

Distopik bilim kurgu filmlerinde gelecek öngörüleri olarak yansıtılan kurguların, bugünün dünyası incelendiğinde, insanları rahatsız edecek kadar tanıdık ve sanıldığından daha benzer olduğu görülmektedir. Ele alınan filmler kurgusal olsalar da insanların yavaş ve emin adımlarla gitmekte olduğu yeri işaret etmektedir.

Çalışma sonucunda gözlemlendiği üzere insanlar organik birer canlı olarak varlıklarını devam ettirdikleri sürece fiziksel mekânların önemlerini yitirse dahi minimal düzeyde varlıklarını sürdürecek olmalarına rağmen 'sanal' mekânların giderek daha fazla önem kazanacağı ve maddeden bağımsız olarak geleceğin mekânlarına dönüşecekleri görülmektedir. Bu dönüşümün insan yaşamında bir takım olumlu sonuçlar doğurmasının yanında, mekânı insani, hissedilir, yaşanan ve deneyimlenen olmaktan uzaklaştırabileceği, sosyal kopukluklara yol açabileceği, insanları yalnızlaştırabileceği, mekânın ve mimarlığın tanımlarını değiştirip dönüştürebileceği düşünülmektedir.

\section{Kaynakça}

Baudrillard, J. (1997). Tüketim toplumu (H. Deliçay ve F. Keskin, Çev.). İstanbul: Ayrıntı Yayınları.

Bay, M. (Yönetmen). (2005). The Island [Film]. U.S.: Warner Bros.

Besson, L. (Yönetmen/Senaryo Yazarı). (1997). The Fifth Element [Film]. U.S.: Columbia Pictures.

Brooker, C., Hug, K. (Yazar) ve Lyn, E. (Yönetmen). (2011). Fifteen Million Merits [Televizyon Dizisi]. Black Mirror içinde. Bölüm: 1. Sezon, 2. Leeds: Channel 4 Broadcasting.

Claeys, G. (2010). The origins of dystopia: Wells, Huxley and Orwell. In Claeys, G. (Ed.), The Cambridge companion to utopian literature (p. 107-132), New York: Cambridge University Press.

Dedeoğlu, F. (2005). Erken 20. yy. düşünsel ortamı ve ev (Yayınlanmamış yüksek lisans tezi). İ.T.Ü. Fen Bilimleri Enstitüsü, İstanbul.

Gilliam, T. (Yönetmen/Senaryo Yazarı). (1985). Brazil [Film]. U.S.: Universal Pictures.

Güngör, A. C. (2015). Animasyon sinemasına ekoeleștirel yaklaşım: "Wall E” filminin incelenmesi. The Turkish Online Journal of Design, Art and Communication - TOJDAC, 5, 1-16.

Harvey, D. (1999). Postmodernliğin durumu (S. Savran, Çev.). İstanbul: Metis Yayınları.

Kutlu, K. (2004). Siberpunk distopya A.Ș. Sinema: Popüler Sinema Dergisi, 5, 92-99.

Lang, F. (Yönetmen). (1927). Metropolis [Film]. U.S.: Paramount Pictures.

Le Guin, U. (2015). Kadınlar rüyalar ejderhalar (M. Gürsoy Sökmen, B. Somay, M. Ahıska, D. Erksan, N. Gürbilek ve S. Tural, Çev.). İstanbul: Metis Yayınları.

Mennel, B. (2008). Cities and cinema. New York: Routledge.

Mitchell, W. (1995). City of bits: Space, place and the infobahn. London: MIT Press.

Niccol, A. (Yönetmen/Senaryo Yazarı). (1997). Gattaca [Film]. U.S.: Columbia Pictures.

Nolan, C. (Yönetmen/Senaryo Yazarı). (2014). Interstellar [Film]. U.S.: Warner Bros.

Nozaki, T., Oshii, M. ve Shirow, M. (1995). The Analysis of Ghost in the Shell. Tokyo: Kodansha Young Magazine.

Oshii, M. (Yönetmen). (1995). Ghost in the Shell [Film]. Japan: Shochiku. 
Oskay, Ü. (1982). Popüler kültür açısından bilim-kurgu ve korku sineması. İstanbul: Ayko Yayınları.

Özakın, Ö. (2001). Bugünün dünyasını geleceğe yansıtmak. Arredamento Mimarlık, 11, 82-87.

Pallasmaa, J. (1995). Identity, intimacy and domicile: a phenomenology of home. The Home: Words, Interpretations, Meanings and Environments, 131-147.

Sobchack, V. (1997). Screening space: The American science fiction film. NewYork: Rutgers University Press.

Sontag, S. (1965). The imagination of disaster. Sontag, S. (Ed.), Against interpretation and other essays içinde (s. 209-225), New York: Picador.

Spielberg, S. (Yönetmen). (2002). Minority Report [Film]. U.S.: 20th Century Fox.

Stanton, A. (Yönetmen/Senaryo Yazarı). (2008). Wall E [Film]. U.S.: Walt Disney Pictures.

Tarkovski, A. (2007). Mühürlenmiş zaman (F. Ant, Çev.). İstanbul: Agora Kitaplığı.

Tong, B. (2005). Distopik bilim-kurgu filmlerindeki mekân çözümlemeleri (1980-2000) (Yayınlanmamış yüksek lisans tezi). İ.T.Ü. Fen Bilimleri Enstitüsü, İstanbul.

Ünver, B. (2016). Mekânsal dönüşümlerin distopik bilimkurgu sineması aracılı̆̆ ile incelenmesi ve mimari öngörüler (Yayınlanmamış doktora tezi). M.S.G.S.Ü. Fen Bilimleri Enstitüsü, İstanbul.

Vural, T. (2005). Değișen üretim - tüketim ilișkileri bağlamında alıșveriș merkezlerinin anlamsal ve mekânsal dönüşümüne eleștirel bir bakış (Yayınlanmamış doktora tezi). İ.T.Ü. Fen Bilimleri Enstitüsü, İstanbul. 